\title{
Recent Advances and Challenges in Controlling the Spatiotemporal Release of Combinatorial Anticancer Drugs from Nanoparticles
}

\author{
Moon Sup Yoon ${ }^{1}$, Yu Jin Lee ${ }^{1}$, Hee Ji Shin ${ }^{1}$, Chun-Woong Park ${ }^{1}$, Sang-Bae Han ${ }^{1}{ }^{1}$, \\ Jae-Kyung Jung ${ }^{1} \mathbb{D}$, Jin-Seok Kim ${ }^{2, *}$ and Dae Hwan Shin ${ }^{1, *}$ \\ 1 College of Pharmacy, Chungbuk National University, Cheongju 28160, Korea; dy5393@gmail.com (M.S.Y.); \\ 5yujinli15@gmail.com (Y.J.L.); xxoodd1@gmail.com (H.J.S.); cwpark@chungbuk.ac.kr (C.-W.P.); \\ shan@chungbuk.ac.kr (S.-B.H.); orgjkjung@chungbuk.ac.kr (J.-K.J.) \\ 2 Drug Information Research Institute, College of Pharmacy, Sookmyung Women's University, \\ Seoul 04310, Korea \\ * Correspondence: jsk9574@sookmyung.ac.kr (J.-S.K.); dshin@chungbuk.ac.kr (D.H.S.); \\ Tel.: +82-02-710-9574 (J.-S.K.); +82-043-261-2820 (D.H.S.); \\ Fax: +82-02-710-0032 (J.-S.K.); +82-043-268-2732(D.H.S.)
}

Received: 20 October 2020; Accepted: 25 November 2020; Published: 27 November 2020

\begin{abstract}
To overcome cancer, various chemotherapeutic studies are in progress; among these, studies on nano-formulated combinatorial drugs (NFCDs) are being actively pursued. NFCDs function via a fusion technology that includes a drug delivery system using nanoparticles as a carrier and a combinatorial drug therapy using two or more drugs. It not only includes the advantages of these two technologies, such as ensuring stability of drugs, selectively transporting drugs to cancer cells, and synergistic effects of two or more drugs, but also has the additional benefit of enabling the spatiotemporal and controlled release of drugs. This spatial and temporal drug release from NFCDs depends on the application of nanotechnology and the composition of the combination drug. In this review, recent advances and challenges in the control of spatiotemporal drug release from NFCDs are provided. To this end, the types of combinatorial drug release for various NFCDs are classified in terms of time and space, and the detailed programming techniques used for this are described. In addition, the advantages of the time and space differences in drug release in terms of anticancer efficacy are introduced in depth.
\end{abstract}

Keywords: nano-formulated combinatorial drug; ratiometric; sequential; spatiotemporal; controlled release

\section{Introduction}

Many studies are being conducted to overcome cancer, a major health problem for humans in modern society. Chemotherapy has been in the spotlight as the main approach for anticancer research, but there are several limitations to this approach [1]. As chemotherapy usually uses a single anticancer drug that targets only one signaling mechanism, many problems such as drug resistance, side effects on healthy tissues, and poor pharmacokinetic profiles are encountered [2-4]. Therefore, combination therapy using two or more different drugs has been considered as a solution for anticancer therapy [5]. However, combination therapy also has its disadvantages. It is difficult to control the pharmacokinetics and pharmacodynamics due to a time difference in drug administration, in which individual drugs are administered in combination, and the possibility of cross-resistance induced by the administration of several drugs [6,7]. Owing to its high level of adaptability, cancer is difficult to treat owing to multiple drug resistance (MDR) that results in simultaneous resistance to multiple drugs with various chemical 
structures and the associated mechanisms of action [8]. To solve these problems, recent research has focused on methods using nanoparticles as nanocarriers in anticancer therapy $[9,10]$.

Nanoparticles have been widely used as vehicles for cancer treatment because of their several advantages, and various nanocarriers such as liposomes, polymeric micelles, silica nanoparticles, chitosan nanoparticles, and protein nanoparticles are being developed [11-15]. The encapsulation of drugs using nanocarriers can help solubilize various poorly water-soluble drugs using nanocarriers with amphiphilic properties [16]. In addition, it is possible to protect drugs through nano-encapsulation or via nanoparticle uptake through endocytosis [17]. A key advantage of using nanoparticles in chemotherapy is the ability to differentiate cancer cells from normal cells and selectively remove cancer cells [18]. Nano-formulated drugs can avoid rapid removal from the body through an enhanced permeability and retention effect (EPR), allowing passive tumor accumulation into tumors, as well as active tumor accumulation by adding ligands for targeting cancer cells [19].

Nano-formulated combinatorial drugs (NFCDs), which can be co-delivered with these nanoparticles, have several unique advantages, such as improving synergistic treatment efficacy, drug resistance management, and the ability to temporarily control drug release [20]. NFCD treatments are considered to have high potential to solve problems such as drug toxicity and dose control, as they can simultaneously utilize the advantages of existing nanoparticles and combination therapy $[8,21,22]$. NFCDs in various formulations can be prepared, depending on the type of nanoparticles to be used and the drug to be combined. Due to these advantages, studies on NFCD are being actively conducted, and some studies have already reached the clinical trial stage [23-27].

We focused on the controlled release of NFCD and confirmed previous studies. NFCDs can be released at the same time or sequentially at intervals of time. In addition, drugs can be released into different spaces. As the anticancer efficacy of NFCDs can vary greatly depending on the drug release pattern from nanoparticles, it is necessary to carefully consider the drug release system according to time and space. Therefore, in this review paper, we classify the types of controlled release of NFCD as ratiometric drug delivery that is simultaneously released over time, sequential drug delivery that is released within cells in order, and sequential drug delivery with intercellular sequential delivery followed by intracellular sequential delivery. We also introduce the advanced technologies of controlled release for this and review the benefits of each controlled drug release pattern and the prospects of these technologies (Figure 1) (Table 1).

Table 1. Characteristics and research progress classified by the release type of nano-formulated combinatorial drugs (NFCDs).

\begin{tabular}{|c|c|c|c|c|c|}
\hline Release Type & Year & Nano Carrier & Used Drug & $\begin{array}{l}\text { Research } \\
\text { Progress }\end{array}$ & Author \\
\hline \multirow{5}{*}{$\begin{array}{l}\text { Ratiometric } \\
\text { drug release }\end{array}$} & 2018 & $\begin{array}{c}\text { VES-g- } \varepsilon \text {-PLL, } \\
\text { dopamine-modified-poly- } \gamma \text {-glutamic } \\
\text { acid polymer ( } \gamma \text {-PGA-Dopa) }\end{array}$ & $\begin{array}{l}\text { Doxurbicin (DOX), } \\
\text { Curcumin }\end{array}$ & In vitro/in vivo & Xu et al. [28] \\
\hline & 2020 & $\begin{array}{l}\text { PEGylated } \varepsilon \text {-poly-L-lysine } \\
\text { polymeric nanoparticles }\end{array}$ & DOX, Lapatinib & In vitro/in vivo & Guo et al. [29] \\
\hline & 2014 & $\begin{array}{l}\text { Dioleoyl phosphatidic acid, } \\
\text { PLGA-PEG-Anisamide NPs }\end{array}$ & $\begin{array}{l}\text { Cisplatin, Gemcitabine } \\
\text { monophosphate }\end{array}$ & In vitro/in vivo & Miao et al. [30] \\
\hline & 2014 & $\begin{array}{l}\text { Poly(lactic-co-glycolic acid) } \\
\text { (PLGA) NPs }\end{array}$ & Rapamycin, Cisplatin & In vitro/in vivo & Guo et al. [31] \\
\hline & 2015 & Xyloglucan, tripeptide Gly-Leu-Gly & DOX, Mitomycin C & In vitro/in vivo & Luo et al. [32] \\
\hline
\end{tabular}


Table 1. Cont

\begin{tabular}{|c|c|c|c|c|c|}
\hline Release Type & Year & Nano Carrier & Used Drug & $\begin{array}{l}\text { Research } \\
\text { Progress }\end{array}$ & Author \\
\hline \multirow{5}{*}{$\begin{array}{c}\text { Sequential } \\
\text { drug release } \\
\text { in intracellular }\end{array}$} & 2017 & $\begin{array}{l}\text { Hollow mesoporous silica } \\
\text { nanoparticles (HMSNs), } \\
\text { PEG-PDS-DPA copolymer }\end{array}$ & Verapamil·HCl, DOX & In vitro & $\begin{array}{c}\text { Palanikumar et al. } \\
\text { [33] }\end{array}$ \\
\hline & 2018 & Janus nanoparticles & DOX, Docetaxel & In vitro/in vivo & $\begin{array}{l}\text { Zhang et al. } \\
\text { [34] }\end{array}$ \\
\hline & 2017 & $\begin{array}{c}\text { Poly(ethyleneglycol)-poly } \\
\text { [2-(methylacryloyl)ethylnicotinate] } \\
\text { (PEG-PMAN) }\end{array}$ & $\begin{array}{c}\beta \text {-Lapachone, } \\
\text { ROS-responsive doxorubicin } \\
\text { (DOX) prodrug }\end{array}$ & In vitro/in vivo & Ye et al. [35] \\
\hline & 2019 & $\begin{array}{c}\text { mPEG-acetalated maltoheptaose } \\
\text { (AcMH)Poly(aspartic } \\
\text { acid)(PAsp)-AcMH }\end{array}$ & $\begin{array}{l}\beta \text {-Lapachone, Niatrogen } \\
\text { mustard (NM) prodrug }\end{array}$ & In vitro/in vivo & Luan et al. [36] \\
\hline & 2019 & PEG-b-poly(D,L-lactic acid) (PDLLA) & $\begin{array}{c}\beta \text {-Lapachone, } \\
\text { Oxidation-resposive } \\
\text { thioether-linked linoleic } \\
\text { aicd-paclitaxel conjugates } \\
\text { (PTX-S-LA) }\end{array}$ & In vitro/in vivo & Wang et al. [37] \\
\hline \multirow{3}{*}{$\begin{array}{l}\text { Spatiotemporal } \\
\text { sequential } \\
\text { drug release }\end{array}$} & 2019 & $\begin{array}{l}\text { [PPLG-g-(CXB-peptide \& } \\
\text { mPEG)]-PEG-PCL (PCxbP) }\end{array}$ & Paclitaxel, Celecoxib & In vitro/in vivo & $\begin{array}{l}\text { Huang et al. } \\
\text { [38] }\end{array}$ \\
\hline & 2019 & mPEG-PLLMA(peptide-CD)-PAsp(DBP) & Paclitaxel, Sunitinib & In vitro/in vivo & He et al. [39] \\
\hline & 2015 & $\begin{array}{l}\text { poly(ethylene glycol)-polyhistidine } \\
\text { (PEG-Phis) polypeptide }\end{array}$ & $\begin{array}{c}\text { Doxorubicin, } \\
\text { Combretastatin A4 }\end{array}$ & In vitro/in vivo & Dong et al. [40] \\
\hline
\end{tabular}
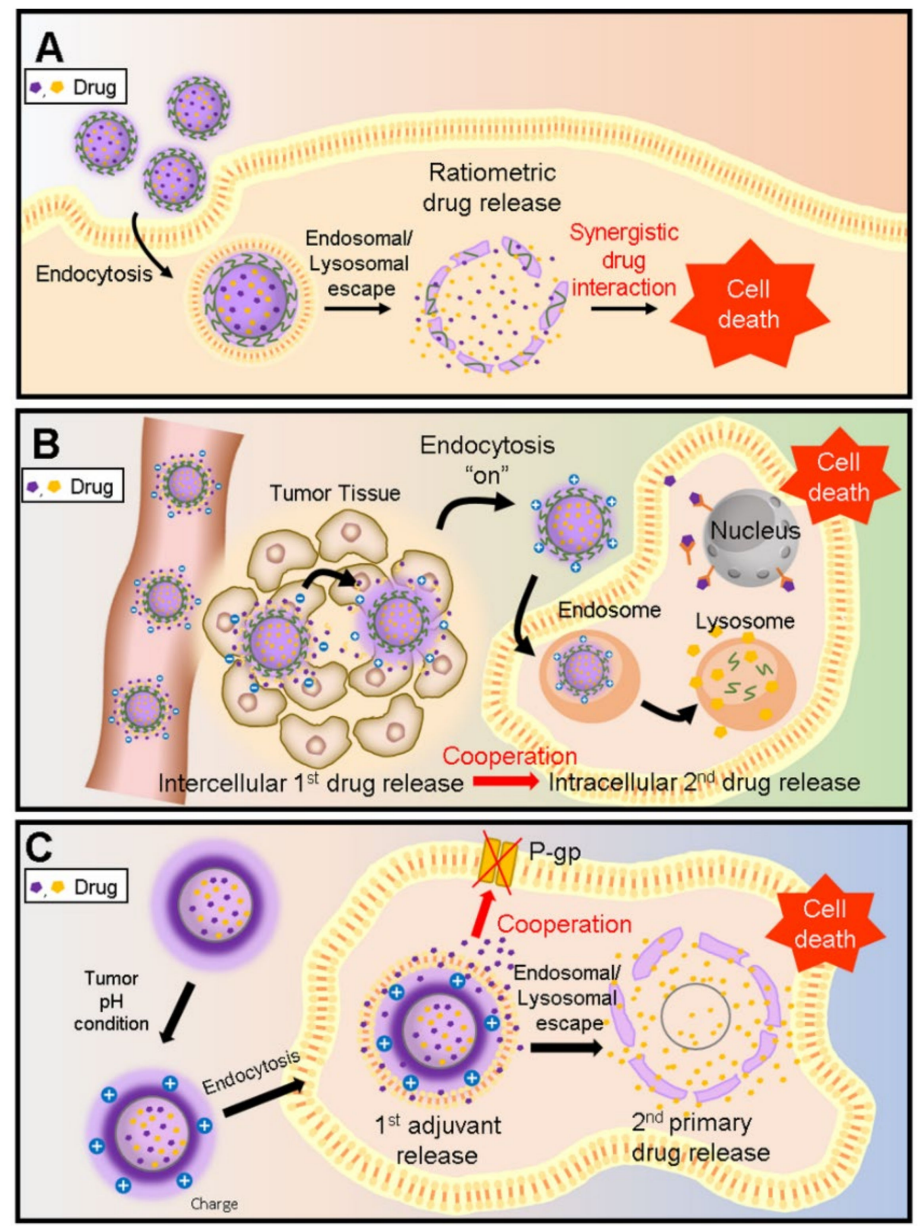

Figure 1. Schematic illustration of various spatiotemporal types of combinatorial anticancer drug release. (A) Ratiometric drug delivery and simultaneous release for synergistic drug interaction. (B) Sequential drug release to achieve both intercellular and intracellular drug action. (C) Intracellular sequential release of adjuvant and primary drug for enhanced drug efficacy. 


\section{Ratiometric Drug Delivery}

By inhibiting cancer via different mechanisms through multi anticancer agents, resistance to anticancer agents can be reduced to a higher degree than when using a single anticancer agent; moreover, a synergistic effect can occur, leading to higher efficiency. For specific combinations to achieve a synergistic anticancer effect, the drugs must be delivered to cancer cells at a fixed constant rate. However, this is difficult owing to the different pharmacokinetic properties of drugs [41]. In addition, the toxicity of drugs to normal cells can cause problems. These problems can be solved using nanoparticles as a carrier for combination drugs. Ratiometric drug release is a drug delivery system that simultaneously releases drugs that are encapsulated in a nanocarrier, and this method can integrate the pharmacokinetics of different drugs (Figure 2) [42]. In the case of ratiometric drug delivery, examples were divided according to how combinatorial drugs were simultaneously released intracellularly, and the techniques used and drug efficacy were discussed.

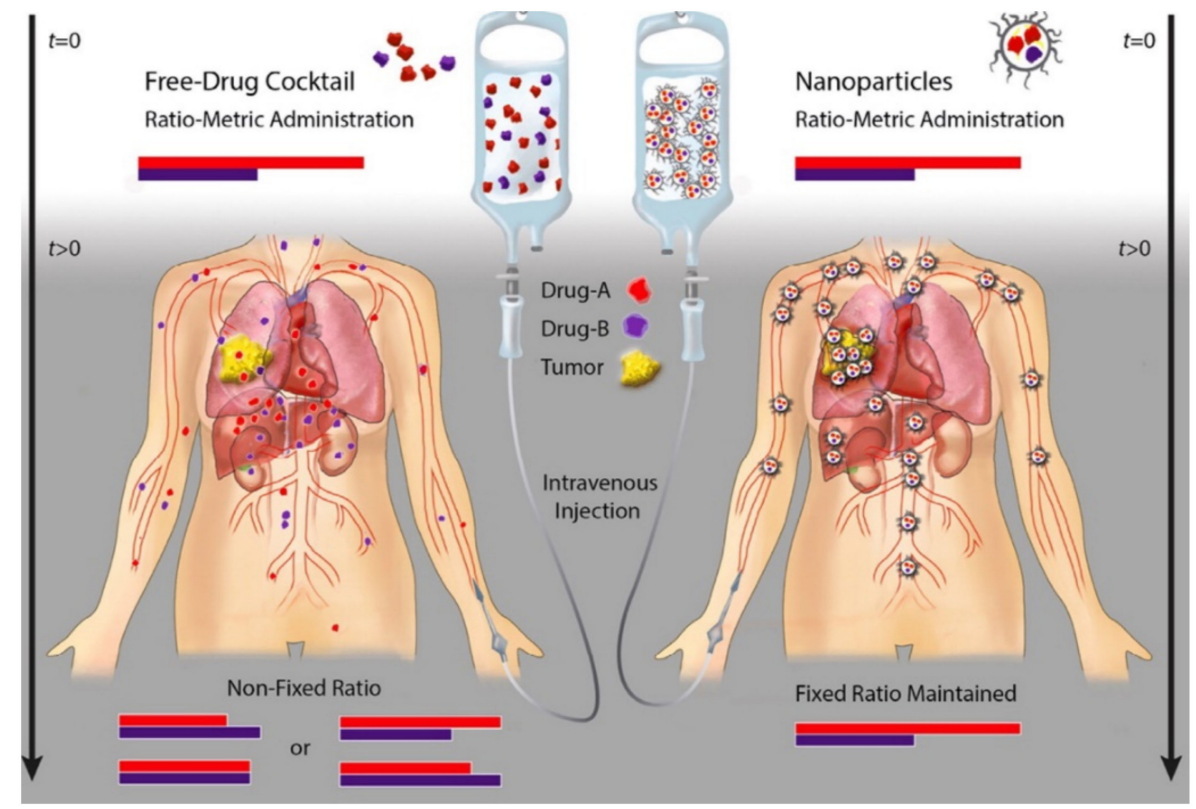

Figure 2. Ratiometric drug delivery of combinatorial drugs using nanoparticles is more advantageous in terms of pharmacokinetics and biodistribution of drug combinations compared to free combinatorial drugs. Reproduced with permission from [40], Journal of Controlled Release, 2016.

\subsection{Release of Co-Loaded Drugs through $\mathrm{pH}$ Control}

Penetration of drugs into tumor tissue is considerably difficult owing to the abnormal extracellular matrix and high cancer cell density [43,44]. Therefore, for better efficacy, anticancer drugs should act more selectively on cancer cells than on normal cells. Tumor tissue has a relatively low $\mathrm{pH}$ than normal cells; therefore, anticancer agents should promote drug release under acidic $\mathrm{pH}$ conditions.

To effectively penetrate tumor tissues, $\mathrm{Xu}$ et al. prepared cationic nanoparticles of VES-g- $\varepsilon$-PLL (Cur-NPs) encapsulating the well-known natural anticancer agent hydrophobic curcumin (Cur) in vitamin E succinate-grafted- $\varepsilon$-polylysine (VES-g- $\varepsilon-P L L) ~[28,45]$. Then, pH-sensitive core-shell nanoparticles (PDCP-NPs) were formed using doxorubicin (DOX) hydrochlorate and Cur-NPs in dopamine-modified-poly- $\gamma$-glutamic acid polymer ( $\gamma$-PGA-Dopa) (Figure 3$)$. In these nanoparticles, $\gamma$-PGA provides a drug-loading site for most primary chemotherapeutic drugs via carboxyl-metal ion coordination or electrostatic interactions. In general, these nanoparticles differ from other nanoparticles combining two drugs in a polymer because DOX is encapsulated in the outer shell. $\gamma$-PGA has high biocompatibility and biodegradability; thus, it is nontoxic to the human body and contributes to the stability of PDCP-NPs in vivo and in vitro. In addition, $\gamma$-PGA improves drug delivery efficiency by 
contributing to the intracellular absorption of cancer cells. The side carboxyl groups of $\gamma$-PGA coated on PDCP-NPs are protonated in acidic conditions to promote the rapid release of DOX. Free amino groups of exposed Cur-NP are also protonated to increase the release rate of Cur from PDCP. Through this process, drugs with different physical properties can be released proportionally. Cur and DOX encapsulated at a ratio of 3:1 in PDCP-NPs were released at a ratio close to 3:1 in cancer cells, and they subsequently inhibited the rapid proliferation of cancer cells and caused apoptosis. In vivo, the PDCP-NP treatment group showed stronger antitumor effects than the single-drug-loaded nanoparticle treatment group. Thus, simultaneous delivery of Cur and DOX showed better treatment efficiency than administration of single-drug-loaded nanoparticles. In addition, tumor volume increased over time in the brain of glioma rats treated with CUR/DOX complex liquid and bilayer $\mathrm{pH}$-sensitive DOX nanoparticles, whereas tumor growth inhibition was observed in mice with treated with PDCP-NPs. Therefore, it was confirmed that the survival rate of mice after PDCP-NP treatment was prolonged compared that of mice after control treatment [28].

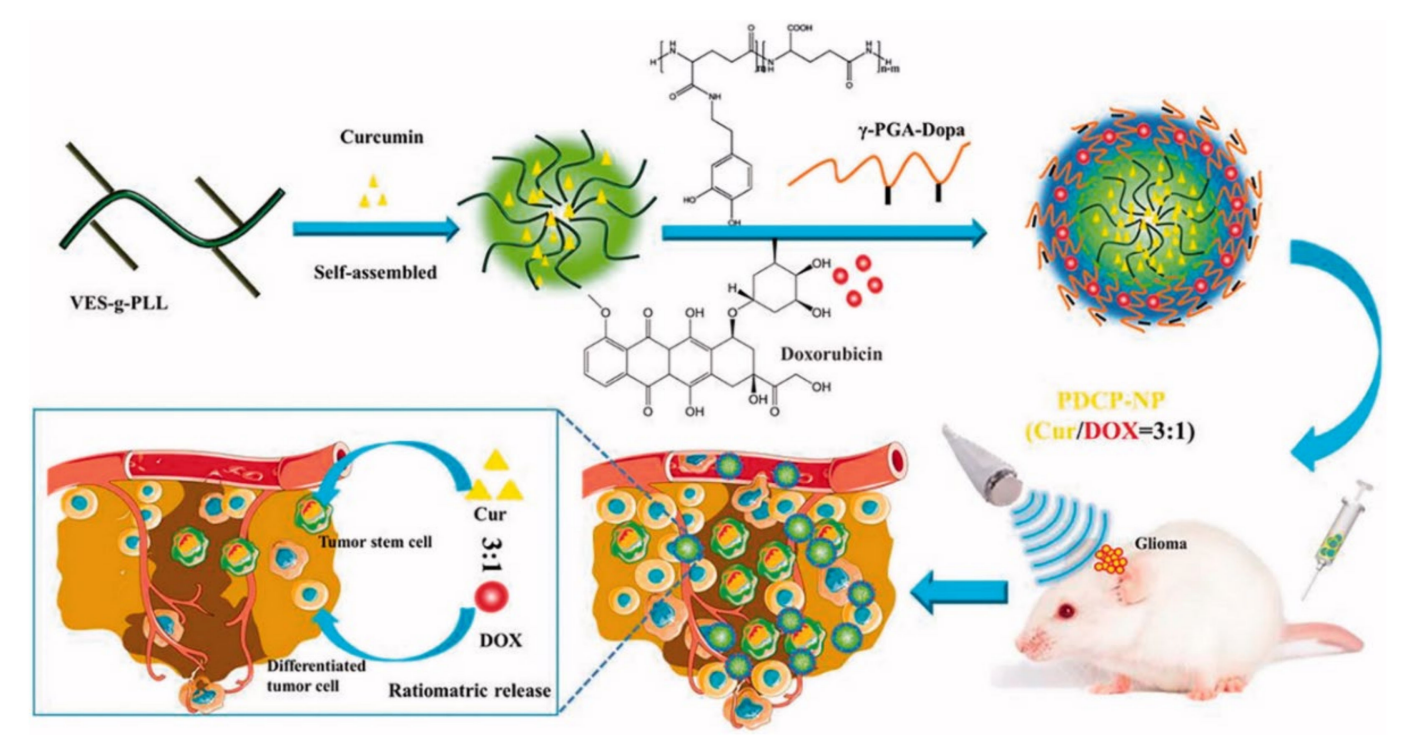

Figure 3. Schematic diagram of $\mathrm{pH}$-sensitive core-shell nanoparticles for ratiometric drug release. The curcumin/doxorubicin co-loaded on the $\mathrm{pH}$-sensitive core-shell nanoparticles is released at a constant ratio in cancer cells. Reproduced with permission from [28], Drug delivery, 2018.

Nanoparticles can accumulate in tumors through the EPR effect, but inefficient intracellular release results in inefficient treatment [46-49]. To solve this problem, Guo et al. studied positively charged polymer nanoparticles to improve drug bioavailability through strong adsorption of negatively charged cell membranes and cationic polymer nanoparticles [29]. The surface of cationic nanoparticles is usually decorated with amino-rich functional groups. One example is $\varepsilon$-poly-L-lysine (EPLYS), a naturally biodegradable homopoly(amino acid), which demonstrated no cytotoxicity with the resultant nanoparticles [29].

Thus, Guo et al. fabricated novel dual drug-loading polymeric nanoparticles using polyethylene glycol (PEG) and EPLYS that physically encapsulated lapatinib (LAP) and DOX (DMMA-P-DOX/LAP nanoparticles) [50-57]. In these polymer-drug conjugates, an acid-cleavable linker was inserted between the drug molecule and the polymer, accelerating the decomposition of the conjugate under intracellular $\mathrm{pH}$ conditions to accurately deliver and release drugs [58-62]. Therefore, DOX was conjugated to the hydrophilic PEG-EPLYS backbone through acid-labile imine bonds, and LAP was physically encapsulated into the nanoparticles; thus, after the cleavage of imine bond, the remaining hydrophobic chain was rendered insufficient, leading to rapid decomposition of nanoparticles. Through these processes, DOX and LAP were simultaneously released. The DMMA-P-DOX/LAP nanoparticle showed that, following intravenous injection, nanoparticles accumulated in the tumor tissue through 
the EPR effect, and the surface charge reversed from negative to positive, enhancing tumor cell internalization $[29,63]$. As a result, the low $\mathrm{pH}$ of the cells caused the cleavage of residual amino groups, thus rapidly breaking down nanoparticles. Therefore, DOX and LAP were simultaneously released accurately into the cytoplasm, effectively inhibiting cell proliferation. As a result of confirming the antitumor effect in vivo, the tumor was more suppressed in the group treated with DOX and LAP nanoparticles compared to the group treated with only free DOX, free LAP, and DOX nanoparticles. In addition, it was confirmed that tumor volume in the DMMA-P-DOX/LAP nanoparticle group decreased more rapidly than that in the DMMA-P-DOX nanoparticle group, and the tumor was completely removed after chemotherapy [29].

Nanoparticles are characterized by stimulus responsiveness for effective drug release at the target site, releasing drugs with environmental changes. Among various stimuli, the $\mathrm{pH}$ of the endosome/lysosome ( $\mathrm{pH}$ 5.0) in cancer cells is relatively lower than that of the extracellular environment; therefore, $\mathrm{pH}$ responsiveness is most often used for ensuring drug release from nanoparticles $[47,64,65]$.

\subsection{Release of Co-Loaded Drugs through Polymeric Degradation}

It is considerably difficult to formulate nanoparticles using drugs with different physicochemical properties [5]. For example, cisplatin is characterized by limited solubility in both water and oil, and gemcitabine monophosphate (GMP) is a hydrophilic drug [66,67]. Cisplatin and GMP have different physicochemical properties and have limitations for loading in nanoparticles. To solve this problem, Miao et al. formulated nanoparticles after wrapping cisplatin and GMP with different characteristics using dioleoyl phosphatidic acid (DOPA) (Figure 4) [30]. Therefore, poly(lactic-co-glycolic acid) (PLGA) nanoparticles were formed using a DOPA-coated cisplatin core (CP core), DOPA-coated GMP core (GMP core), and PLGA. To further improve the internalization of PLGA nanoparticles into cancer cells, a ligand that acts with a receptor overexpressed on the surface of cancer cells was introduced into PLGA nanoparticles. The prerequisite for control of delivery in this way is to incorporate the physicochemical properties of the dual drugs by taking advantage of the similarities of the surface and size of the core. The advantage of this method is that it avoids functional indirection between individual molecules, allowing for precise ratio loading and delivery. In addition, the optimal combination drug ratio was more effective than single nanoparticles loaded with GMP and cisplatin separately, and it showed remarkable anticancer efficacy $[2,68]$.

It was confirmed that the $\mathrm{IC}_{50}$ value of PLGA NP loaded into CP cores and GMP cores (combo NP) was smaller than the GMP nanoparticle and cisplatin nanoparticle. In addition to in vivo antitumor efficacy for tumor transplant models, combo free administration showed that the weight of the tumor was lower than that of the tumor when free cisplatin and free GMP were injected. On the other hand, the $\mathrm{IC}_{50}$ value of combo NP was larger than that of combo free, but there was no significant difference. The tumor weight was lower when a separate NP was injected than that when cisplatin NP and GMP NP were administered, and the tumor weight when combo NP was administered was the lowest. These results show that combination NPs containing cisplatin and GMP exhibited improved anticancer effects compared with a single drug.

In another study, rapamycin (RAPA), an mTOR inhibitor, was combined with cisplatin. It was shown that co-delivery of RAPA with cisplatin could significantly promote the efficacy of RAPA through microenvironment regulation $[69,70]$. However, encapsulating these drugs in PLGA NPs was inefficient owing to the incompatibility between the two drugs and the polymer matrix. Here, as in the previous example, the nano precipitate (cores) of the drug was coated with DOPA to make cisplatin hydrophobic [66,71,72]. Guo et al. attempted to co-encapsulate DOPA-coated cisplatin and RAPA in PLGA NPs using a solvent displacement method to improve the encapsulation and loading efficiency of the hydrophobic drugs [31]. The combination NPs showed sustained release of both cisplatin and RAPA, with similar release rates. This release rate suggests that the explosive release of cisplatin from PLGA NPs was prevented by the hydrophobic DOPA coating. In addition, the $\mathrm{IC}_{50}$ of combined drug was lower than that of the single drugs, and the $\mathrm{IC}_{50}$ of the PLGA-NP-encapsulated drug was lower 
than that of the free drug, showing better anticancer effect. In addition, in the in vivo experiment, it was confirmed that the tumor size decreased when (RAPA + cisplatin) NP was administered compared to when cisplatin NPs, RAPA NPs, and RAPA NPs + cisplatin NPs were administered [31].
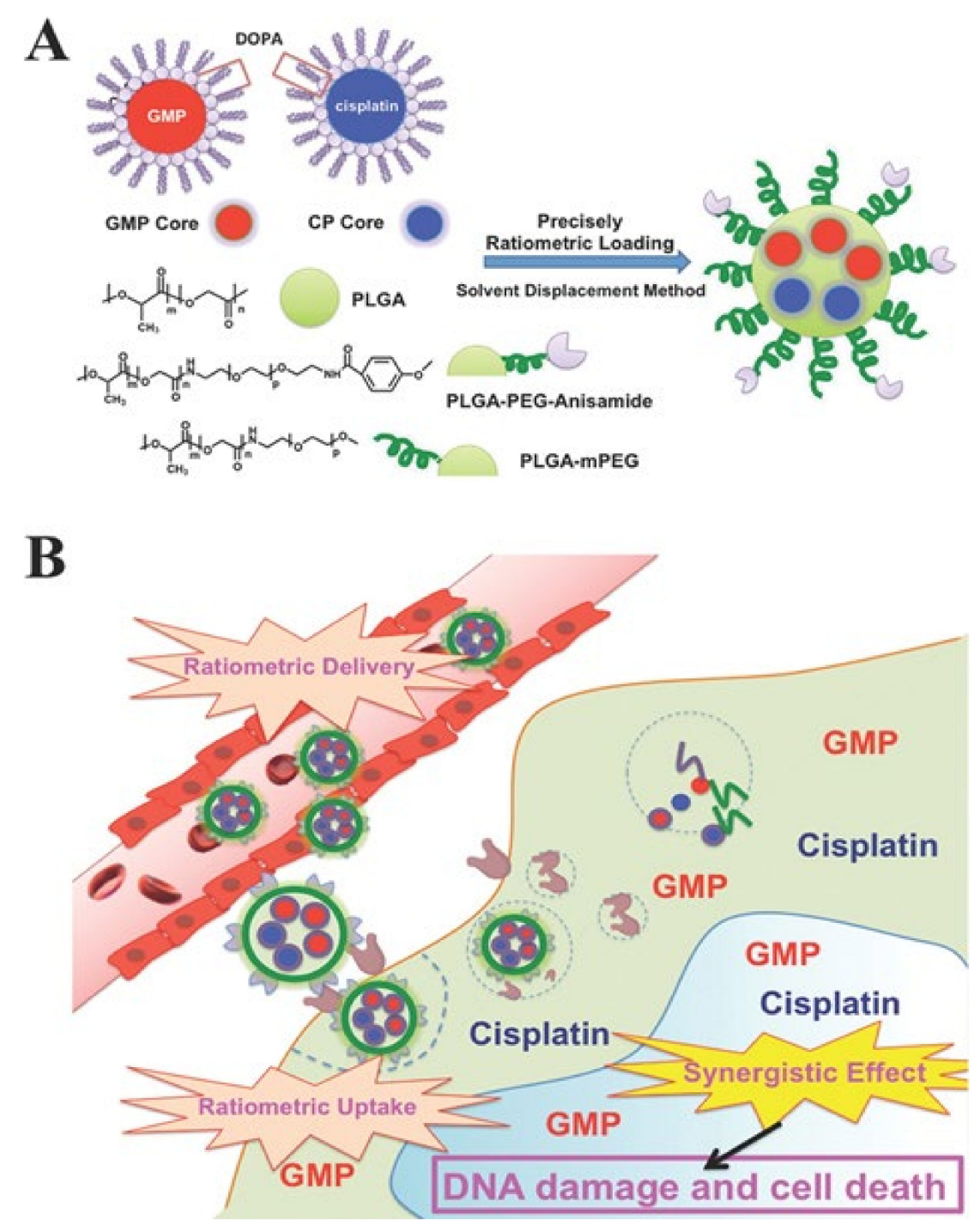

Figure 4. (A) Schematic diagram of PLGA-PEG-Anisamide NP (PLGA NP) including a dioleoyl phosphatidic acid (DOPA)-coated cisplatin core (CP core) and DOPA-coated gemcitabine monophosphate core (GMP core) through solvent substitution method. (B) Ratiometric drug delivery of CP core and GMP core co-loaded PLGA nanoparticles (combination NP) into cancer cells. Reproduced with permission from [30], Advanced Functional Materials, 2014.

Therefore, encapsulation of a hydrophilic phosphorylated drug generated via lipid coating of the surface layer of the calcium phosphate core using DOPA is an efficient method for achieving ratiometric drug delivery.

\subsection{The Release of Co-Loaded Drugs through Enzymatic Degradation}

Drug delivery systems that use polymer-drug conjugates not only have advantages such as reduction of drug toxicity, tumor accumulation through the EPR effect, and improvement of bioavailability, but they can also control the molar ratio of different drugs more elaborately than the drug encapsulation method using nanoparticles [73-77]. Drug-polymer conjugates have succeeded in maintaining the ratio between several different drugs, but the ratiometric release of different drugs 
from a carrier is still a difficult task due to the variability of drug and polymer interaction and the steric hindrance of drugs [20,78-81].

To compensate for this problem, Luo et al. studied a novel method of loading double drugs into a macromolecular carrier at different molar ratios of DOX and mitomycin C (MMC), which are widely known anticancer agents; however, they have serious side effects when administered as free drugs $[32,76,82]$. As a drug carrier, xyloglucan (XG), a natural and nontoxic polysaccharide was used, and tripeptide Gly-Leu-Gly which is degraded by lysosomal enzymes was used as a linker capable of attaching DOX and MMC to the XG [83-85]. XG-MMC/DOX was formulated using the anticancer drugs DOX and MMC, the carrier XG, and the linker tripeptide Gly-Leu-Gly that attaches the drug and the carrier. XG-MMC/DOX accumulates in the tumor via the EPR effect and reaches the lysosomal compartment of cancer cells, whereas the linker is degraded by the lysosomal enzymes, leading to drug release from the $\mathrm{XG}$, thereby enabling efficient ratiometric drug release in cancer cells [86]. XG-MMC/DOX showed a superior anticancer effect in in vitro and in vivo cytotoxicity studies compared to cocktail mixtures of anticancer drugs such as XG-MMC and XG-DOX. Therefore, a polymer-drug conjugate complex, which uses a linker such as tripeptide Gly-Leu-Gly, is considered to have sufficient advantages for ratiometric drug delivery for anticancer therapy.

Ratiometric drug release is an important release technology that increases the efficacy of drugs by controlling the pharmacokinetics of two different drugs, delivering drugs better to the target than cocktail therapy. However, more advanced strategies are needed that further consider the MDR.

\section{Sequential Drug Release}

Although the co-administration of multiple drugs is a major strategy to overcome drug resistance, it might limit the synergistic effects of drugs in a heterogeneous tumor environment $[81,87,88]$. As the research on NFCDs continued, it was confirmed through advanced studies that not only were NFCDs released in a ratiometric manner in cancer cells but also sequentially (time or space differences). As drugs show differences in solubility or cancer-inhibitory mechanisms, there are cases where sequential release of drugs from NFCD complexes is advantageous. In addition, sequential release can be spatiotemporal, in which drugs are released only in the predetermined order of release within cancer cells. Therefore, we divided sequential drug release into intracellular sequential drug release, in which drugs are released only inside cancer cells in a certain release sequence, and spatiotemporal drug release, in which drugs are released site-specifically outside and inside cancer cells.

\subsection{Intracellular Sequential Drug Release}

The sequential release of NFCDs in cells is a temporal concept of drug release. The characteristic of this technology is that, unlike in conventional ratiometric release, the order in which drugs are released affects their anticancer efficacy. For example, in the delivery of a P-glycoprotein (P-gp) inhibitor and an anticancer drug, rather than releasing the two drugs ratiometrically into the cell at the same time, the P-gp inhibitor is released first to inhibit P-gp, followed by the release of the anticancer agent to more efficiently overcome MDR [89]. In addition, sequential release of drugs can lead to improved safety and reduced toxicity. Therefore, there is a need for nanoparticle formulations that can sequentially release several drugs at the target site. We divided the cases into the mechanism via which two drugs directly affect cancer cells through sequential release and the mechanism via which one drug amplifies the effect of other drug.

\subsubsection{Sequential Drug Release of Co-Loaded Drugs That Directly Affect Cancer Cells}

The research below describes an example of using hollow mesoporous silica nanoparticles (HMSNs) as part of a combination drug carrier (Figure 5). Hydrophilic anticancer agents can be loaded into HMSNs, and hydrophobic anticancer agents can be loaded through physical adsorption on the mesoporous surface of HMSNs, compared to conventional NFCDs that are loaded with poorly soluble drugs [90-93]. Pristine mesoporous silica nanoparticles (MSNs) have the disadvantage that the drug 
can be released before reaching a specific target [94]. Therefore, in order to overcome this drawback, polymer-coated HMSNs (PHMSNs) were prepared by coating a positively charged PEG-PDS-DPA copolymer on negatively charged HMSNs through electrostatic interactions. PHMSNs have stable colloidal properties, and selective drug delivery for specific targets (cancer cells) is possible [95]. It was proven through a $\mathrm{pH}$-dependent cell uptake assay that co-drug-loaded PHMSNs do not release drugs under the $\mathrm{pH}$ conditions of normal tissue or blood (7.4), but exhibit the ability to release $\mathrm{pH}$-reactive drugs under the $\mathrm{pH}$ conditions of tumors (5.5). In addition, after PHMSNs are internalized into cancer cells, the swelling of the polymer gatekeeper induces the release of the hydrophilic drug in the acidic environment of the endosome, and the hydrophilic drug is released first. In the cytoplasm, the polymer gatekeeper is cleaved by glutathione to release a hydrophobic drug, and it has been demonstrated that a controlled sequential release is possible in the cell.

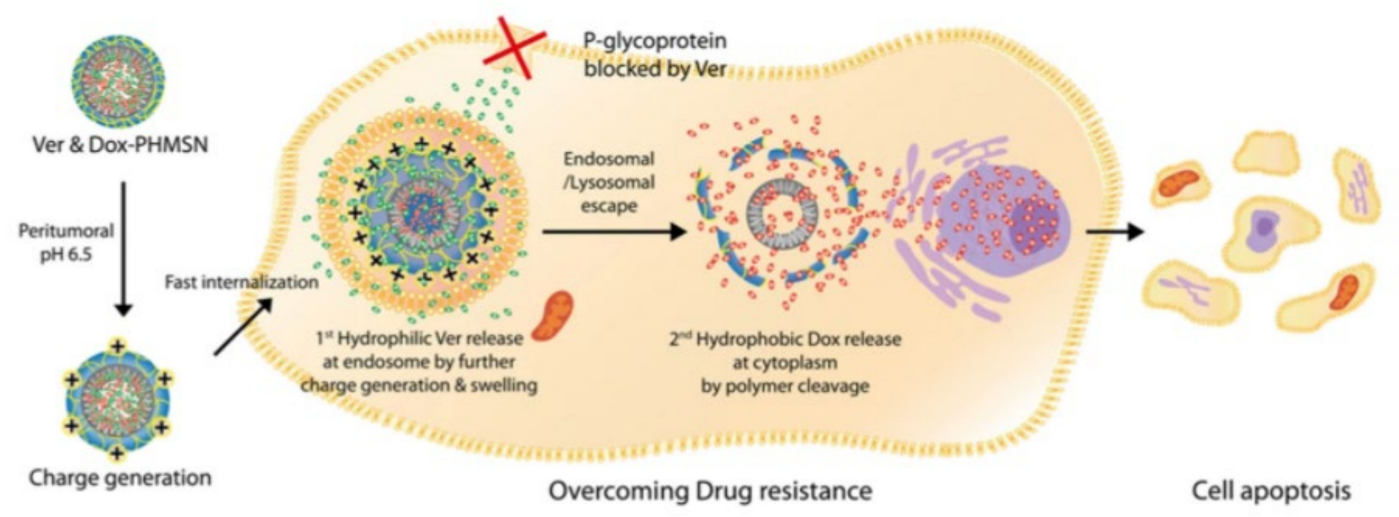

Figure 5. Sequential release of hydrophobic, hydrophilic drugs from polymer gatekeeper hollow mesoporous silica nanoparticles (PHMSNs). PHMSNs become positively charged in the $\mathrm{pH}$ condition of the tumor and are rapidly internalized into cells. Then, by the swelling of the polymer gatekeeper, the hydrophilic drug verepamil. $\mathrm{HCl}$ is initially released to inhibit P-glycoprotein, and the hydrophobic anticancer drug doxorubicin is later released causing cell apoptosis. Reproduced with permission from [33], Advanced Functional Materials, 2017.

Such intracellular sequential drug release of co-drug-loaded PHMSNs can be a solution to MDR. Multidrug efflux pumps, such as P-gp, reduce the drug concentration in the cytoplasm through the plasma membrane to reduce the anticancer effect of the drug [96]. Hydrophilic verapamil. $\mathrm{HCl}$, a calcium channel-blocking agent, is an inhibitor of P-gp and increases the accumulation of anticancer drugs in cancer cells by preventing anticancer drugs from escaping to the outside of the cell through the P-gp [97]. On conducting cytotoxicity assays of hydrophilic verapamil. $\mathrm{HCl}$, hydrophobic DOX co-loaded PHSMNs, and free DOX in P-gp overexpressed breast cancer cell lines, it was confirmed that the former has stronger cytotoxic effects. Therefore, this strategy, wherein verapamil. $\mathrm{HCl}$, an inhibitor of P-gp, is initially released, controls P-gp, and then sequentially releases anticancer drugs, is thought to be an effective option to treat cancer.

Janus nanoparticles (JNPs) can also be used to sequentially release hydrophilic and hydrophobic anticancer agents which can directly affect cancer cells. JNPs can have two or more different physical properties at the same time owing to their heterogenous structure and functionalities, which allow both hydrophilic and hydrophobic drugs to be loaded into the differing components of the structure and to be released via different stimuli [98-102]. DOX and docetaxel (DOC), the most well known anticancer drugs with different cancer cell-inhibitory mechanisms, showed a synergistic therapeutic effect with a combination index lower than 1 when used as a cocktail therapy; nevertheless, owing to their different solubility, the two drugs were difficult to be incorporated into nanoparticles, and their sequential release in cancer cells was even more difficult [103-105]. 
To prepare JNPs to co-load and sequentially release DOX and DOC, Zhang et al. first prepared Ag nanocube/poly(acrylic acid) (AgNC/PAA) by mixing AgNC and PAA. AgNC/Fe(OH) ${ }_{3}$-PAA was prepared by growing $\mathrm{Fe}(\mathrm{OH})_{3}$ in the PAA part of AgNC/PAA to ensure loading of hydrophilic DOX and release of DOX in response to $\mathrm{pH}$ stimulation [34]. Then, $\mathrm{AgNC}$ was etched with $\mathrm{HAuCl}_{4}$ to form AuNC through a galvanic exchange reaction to prepare $\mathrm{AuNC} / \mathrm{Fe}(\mathrm{OH})_{3}-\mathrm{PAA} J N P s$. Lastly, PCL-AuNC/Fe(OH) 3 -PAA JNPs were synthesized by modifying AuNC with PCL-SH to obtain the ability to load hydrophobic DOC, the photothermal effect, and the release properties allowing DOC release in response to near-infrared (NIR) stimulation [106].

DOC- and DOX-loaded PCL-AuNC/Fe(OH) $)_{3}$-PAA JNPs (DDPs) are taken up into the cytoplasm through lysosomes or endosomes, via the EPR effect. Hydrophilic DOX, loaded in the $\mathrm{Fe}(\mathrm{OH})_{3}-\mathrm{PAA}$ part of JNPs, is first released in response to low $\mathrm{pH}$ of the cytoplasm (pH 5.5). Next, upon NIR laser irradiation, the hydrophobic DOX loaded in the PCL-AuNC part of JNPs is released in response to NIR stimulation. NIR laser irradiation not only triggers DOC release but also causes an additional photothermal effect, resulting in a higher chemotherapy effect in cancer cells [107-109]. In H-22 liver cancer model mice, the anticancer efficacy of NIR laser-irradiated DDPs was superior to that of general DDPs, single free drugs, and free drug combinations. In addition, the DOC/JNP and DOX/JNP cocktail showed inferior drug efficacy to the combination of free drugs owing to unintended cell-cycle arrest, which was attributed to inappropriate sequential drug release and decreased response to subsequent drugs. Therefore, the photothermal effect induced by NIR laser irradiation was confirmed in DDPs, and it is important that DOC and DOX were released sequentially.

\subsubsection{Sequential Drug Release Where One of the Co-Loaded Drugs Amplifies the Effect of the} Other Drug

Reactive oxygen is an unstable molecule. When reactive oxygen species accumulate in a cell, DNA, RNA, and proteins are damaged, and apoptosis can occur [110]. Using the specific role of these ROS, we introduce an NFCD delivery system that acts specifically on cancer cells. Stimulus-responsive drug delivery systems are technologies that target cancer cells by releasing stimulus-responsive drugs accumulated in cancer cells by glutathione (GSH), $\mathrm{pH}$, and ROS [111-113]. In cancer cells and normal cells, when GSH-based and pH-based drug release systems are used, the selectivity is not high; however, ROS such as hydrogen peroxides $\left(\mathrm{H}_{2} \mathrm{O}_{2}\right)$ and hydroxyl radicals $\left(\mathrm{OH}^{\bullet}\right)$ can have high selectivity because cancer cells have more than 10-fold the levels of normal cells [114-118]. However, cancer cells have heterogeneity and, thus, it might be difficult to fully realize the ROS-responsive release effect [119]. Therefore, to increase the selectivity for cancer cells, a cascade amplification strategy was used to increase the ROS concentrations to a greater extent [120].

Drugs that amplify ROS include D-amino acid oxidase, vitamin $C, \beta$-lapachone, cinnamaldehyde, etc. [121-124]. Ye et al. employed a technique using cascade amplification release nanoparticle (CARN), which is formed by encapsulating the ROS-responsive DOX prodrug (BDOX) and $\beta$-lapachone together in poly(ethylene glycol)-poly[[2-(methylacryloyl)ethylnicotinate] (PEG-PMAN) [35]. $\beta$-Lapachone has a very low encapsulation efficiency for commonly used polymers such as poly(ethylene glycol)-block-poly(lactic acid) (PEG- $b$-PLA). Therefore, PEG-PMAN was prepared using atom transfer radical polymerization to increase the encapsulation efficiency (Figure 6). When CARNs are injected intravenously, they travel through the blood vessels and accumulate in cancer cells due to the EPR effect of the cancer cell membrane. After that, $\beta$-lapachone, released first from the nanoparticles, amplifies ROS using the nicotinamide adenine dinucleotide (phosphate) $(\mathrm{NAD}(\mathrm{P}) \mathrm{H})$ :quinone oxidoreductase-1 (NQO1) enzyme, ultimately promoting DOX release from BDOX [125]. Unlike DOX, which is released in a $\mathrm{pH}$-dependent manner, $\mathrm{BDOX}$ can suppress unwanted drug release as the release is not affected by changes in $\mathrm{pH}$ [35]. Since NQO1 is overexpressed in cancer cells compared to levels in normal cells, $\beta$-lapachone can function effectively in cancer cells [126]. In other words, CARNs that cannot generate sufficient ROS in normal cells with low NQO1 expression show low cytotoxicity toward normal cells. ROS amplified by $\beta$-lapachone blocks the function of P-gp, thereby preventing the drug from being 
released from the cells and consequently lowering MDR [127]. In addition, ROS moves DOX into the nucleus and DOX affects DNA and topoisomerase II, causing apoptosis [128-133]. DOX causes necrosis of cardiomyocytes due to its side effect that causes cardiac toxicity [134]. However, according to the results of a histological study, CARNs administered to mice did not cause DOX-induced cardiac toxicity. In addition, when phosphate-buffered saline (PBS), DOX, and CARN were administered to mice, there was no significant difference in body weight between PBS and CARN. In contrast, DOX showed significant body weight reduction. Therefore, it could be confirmed that CARN does not show toxicity.

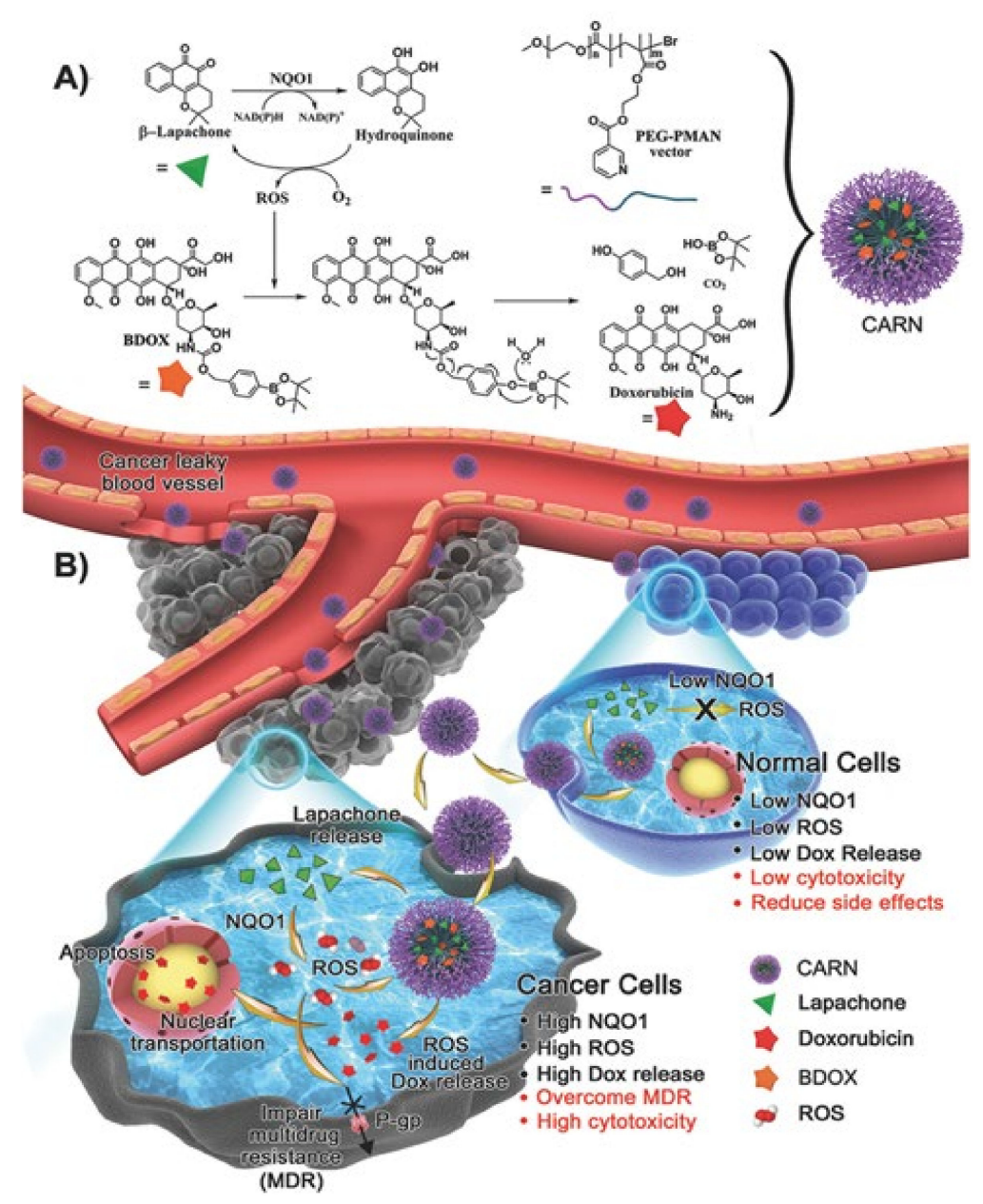

Figure 6. Cascade amplification release nanoparticle (CARN) formation process and its sequential release system. (A) Structure of BDOX, $\beta$-lapachone, and PEG-PMAN constituting CARN. (B) CARNs, which move through blood vessels, are accumulated in cancer cells. When $\beta$-lapachone is initially released from the nanoparticles, it amplifies reactive oxygen species (ROS). The amplified ROS blocks P-glycoprotein (P-gp), preventing DOX from escaping out of the cell. It also changes BDOX to DOX, causing apoptosis. Reproduced with permission from [35], Advanced Materials, 2017.

When creating an effective drug delivery system, it is better to find a material with good biodegradability and biocompatibility $[135,136]$. Glucan, one of the materials with excellent biocompatibility and water solubility, is a polysaccharide that many researchers are exploring $[137,138]$. In particular, because acetylated glucan is sensitive to $\mathrm{pH}$, it changes from hydrophobic to hydrophilic in a low-acidic environment. In addition, polymers such as poly(glycolic acid) or poly(lactic acid) are used as materials to increase biodegradability [139]. However, the decomposition products of these polymers under acidic conditions can cause side effects such as allergic reactions and inflammation [140-143]. In contrast, polyamino acid chains are characterized by remarkable biocompatibility, perfect biodegradability, 
and low toxicity $[144,145]$. Therefore, Luan et al. formed nanoparticle(P-NM-Lapa) with polyaspartic acid-acetylated maltoheptaose (PAsp-AcMH) composed of (AcMH) and (PAsp), mPEG-AcMH composed of AcMH and nontoxic PEG, and $\beta$-lapachone and positively charged nitrogen mustard (NM) prodrug [36]. P-NM-Lapa decomposes AcMH in an acidic environment, releasing $\beta$-lapachone and NM prodrugs. Although NM is an alkylating agent with anticancer effects, it has a short half-life in blood and can cause mutations on its own [146-150]. It also responds well to the DNA of normal cells and tumor cells, making it difficult to effectively target tumor cells [151]. However, P-NM-Lapa does not cause toxicity in normal tissues. In histological study, when administered to mice, vacuolization occurred in the tumor, but there was no significant difference from PBS in the liver, heart, and kidney. Therefore, this means that P-NM-Lapa is more stable in the body and has no toxic side effects compared to when DOX was administered. In addition, by using $\beta$-lapachone together with a NM prodrug that reacts with $\mathrm{H}_{2} \mathrm{O}_{2}$ and has less toxicity, a synergistic effect and selective expression in cancer cells can be realized [36].

In another study by Wang et al., nanoparticles (LPC/PTX-S-LA PMs) with oxidation-responsive thioether-linked linoleic acid PTX conjugates (PTX-S-LA) and $\beta$-lapachone enclosed in PEG- $b$-poly(D,Llactic acid) (PEG-PDLLA) as a ROS-responsive drug delivery system were used [37,152-154]. Likewise, $\beta$-lapachone increases ROS, and PTX is released from PTX-S-LA, which effectively acts on cancer cells (Figure 7). When LPC/PTX-S-LA PMs were administered to $4 \mathrm{~T} 1$ tumor-bearing BALB/c female mice, the tumor growth-inhibitory effect was greater than when taxol was administered. This is because PTX-S-LA showed a high rate of accumulation in tumors by ROS. In addition, no significant change in body weight was observed in mice.

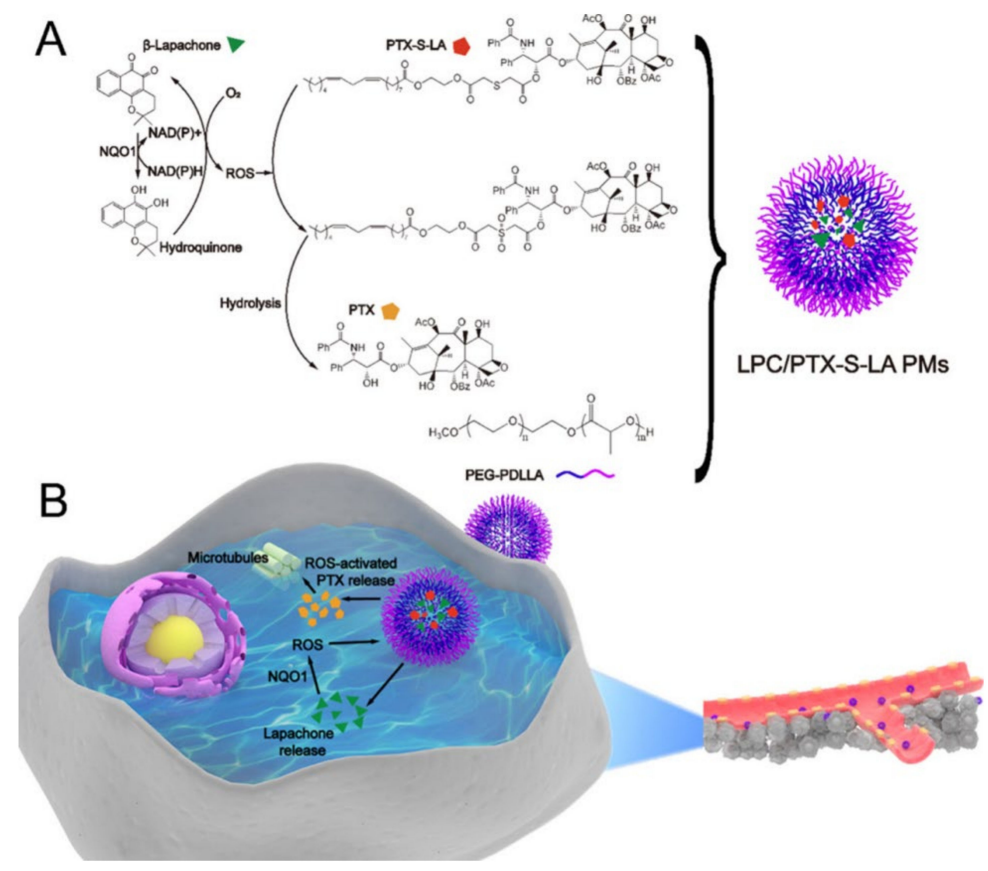

Figure 7. Sequential release by prodrug nanosystem. (A) Structure and nanoparticle formation process for $\beta$-lapachone (LPC), oxidation-responsive thioether-linked linoleic acid paclitaxel conjugates (PTX-S-LA), and PEG-b-poly(D,L-lactic acid) (PEG-PDLLA) (B) Upon intravenous injection, LPC/PTX-S-LA polymeric micelles (PMs) migrate into cancer cells due to the enhanced permeability and retention (EPR) effect. These nanoparticles release LPC first, overexpressing nicotinamide adenine dinucleotide (phosphate) $(\mathrm{NAD}(\mathrm{P}) \mathrm{H})$ :quinone oxidoreductase-1 (NQO1), and raising the ROS level. Then, ROS promotes the release of PTX from PTX-S-LA, and PTX induces apoptosis. Reproduced with permission from [37], American Chemical Society, 2019. 
We reviewed a drug delivery system using ROS that can act more effectively against cancer cells than normal cells. The primary feature of sequential drug release using ROS is the selection of drugs in the polymer. Assuming that two drugs are used in combination to form nanoparticles, it is important to select a combination wherein one drug can amplify ROS and the other drug is effectively expressed against the amplified ROS, leading to high anticancer effects. The second feature is the choice of polymer. Above all, it should be able to encapsulate the two drugs of choice, it should be degraded more in cancer cells due to their acidic conditions compared to normal cells, and the polymer should be harmless, biocompatible, and biodegradable.

\subsection{Sequential Drug Release to Achieve both Intercellular and Intracellular (Spatiotemporal) Drug Release}

The aforementioned studies suggested that, even if the drug release profile of NFCDs is ratiometric or sequential, it is difficult to completely treat cancer using these release profiles owing to the characteristics of solid tumor microenvironment (TME). The TME is both heterogeneous and complex as it contains various tumor tissues, including subgroups of genetically diverse cancer cells and nonmalignant stromal cells, which promote tumor cell survival, growth, and resistance to drugs during treatment [155-159]. Therefore, an effective cancer strategy that not only targets cancer cells but also the TME is needed. Thus, taking TME into consideration, NFCDs capable of spatiotemporal controlled release, which is a new paradigm where drugs related to TME treatment are first released in the TME and then internalized into cancer cells to release anticancer agents, are being developed in recent anticancer studies [160].

\subsubsection{Spatiotemporal Drugs Release by Matrix Metalloproteinase-2 (MMP-2)}

Proinflammatory mediators, such as cyclooxygenase-2 (COX-2) and COX-2-derived prostaglandins $2\left(\mathrm{PGE}_{2}\right)$, have a profound effect on tumor survival, growth, metastasis, and angiogenesis [161,162]. Chemotherapy often induces the upregulation of the proinflammatory mediators mentioned above and antiapoptotic genes, causing malignant cells to develop resistance to chemotherapy agents $[163,164]$. Celecoxib (CXB), a nonsteroidal anti-inflammatory drug can not only affect cancer characteristics by inhibiting the inflammatory $\mathrm{COX}-2 / \mathrm{PGE}_{2}$ pathway, but also reduce chemical resistance by inhibiting antiapoptotic genes $[165,166]$. Therefore, combination therapy with chemotherapy drugs and nonsteroidal anti-inflammatory drugs can be a new way to change the proinflammatory environment of tumors and to make cancer sensitive to anticancer drugs [167].

Several clinical trials have begun for these combination drugs; it is difficult to achieve a desirable synergistic anticancer effect because anti-inflammatory drugs are generally administered in free form in clinical studies [168-171]. In addition, the long-term administration of nonsteroidal anti-inflammatory drugs in free form can cause serious side effects [172].

To solve these problems, Huang et al. succeeded in achieving spatiotemporal controlled release so that anti-inflammatory agents can act on various cell types and are released from tissues, while chemotherapeutic agents target and are released in cancer cells [38]. Briefly, considering that the peptide with the PLGLAG is sensitive to MMP-2, abundantly present in tumor tissue, CXB was conjugated to the GGPLGLAGG peptide, and the triblock copolymer [PPLG-g-(CXB-peptide \& mPEG)]-PEG-PCL (PCxbP) was manufactured through a click reaction with a prepolymer $[173,174]$. In this triblock copolymer, PTX was encapsulated into the micelle core through the hydrophobic interaction of poly ( $\varepsilon$-caprolactone) (PCL) and PTX in an aqueous solution, to complete the MMP-2sensitive nanospheres loaded with the anti-inflammatory agent $C X B$ and the anticancer agent PTX (MSN-CXB/PTX) $[175,176]$. After the MSN-CXB/PTX entered the tumor tissue, CXB was released by the concentrated MMP-2, and the negatively charged nanospheres were converted into positively charged nanospheres, which enhanced internalization (Figure 8). 


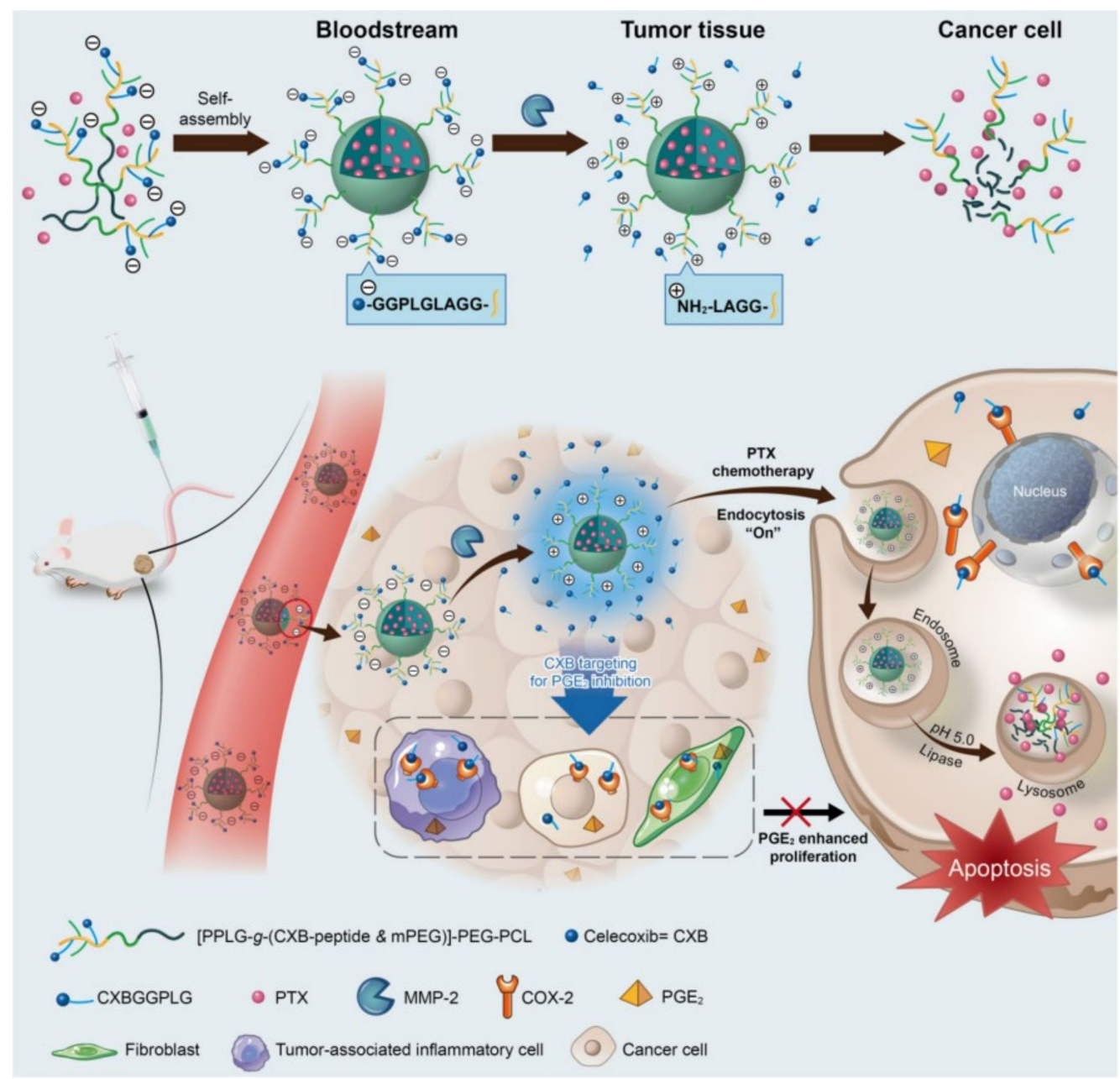

Figure 8. Combinatorial drug-loaded nanospheres capable of spatially sequential drug release using matrix metalloproteinase-2 (MMP-2) sensitive peptide. Celecoxib is first released into the tumor tissue by MMP-2, which is then activated in the tumor environment; paclitaxel (PTX)-loaded nanospheres are positively charged and internalized into cancer cells, and PTX is released intracellularly, causing apoptosis. Reproduced with permission from [38], American Chemical Society, 2019.

In an in vivo anticancer effect study in nude mice bearing HT-1080 tumor, it was confirmed through tumor size and survival rate that MSN-CXB/PTX showed a better therapeutic effect than the control groups (PBS, MMP-2-insenitive nanospheres loaded with single drug (MIN-PTX, MIN-CXB, and MIN loaded with CXB/PTX (MIN-CXB/PTX)). In addition, quantitative analysis of $\mathrm{PGE}_{2}, \mathrm{COX}-2$, and anti-apoptotic BCL-2 proteins that induce resistance to chemotherapy in mice tumor tissues showed that MSN-CXB/PTX effectively inhibited the COX-2/PGE 2 pathway and the expression of BCL-2 proteins, thus having superior tumor cell death compared to control groups [166].

Therefore, MSN-CXB/PTX, which is capable of site-specific release, is considered to be suitable as a cancer cell therapy agent by efficiently solving the resistance problem of cancer cells.

There was another study by He et al. on the spatiotemporal controlled release of NFCDs considering the TME using MMP-2-sensitive peptides [39]. As a combination drug, sunitinib, an angiogenesis inhibitor that has been used with other chemotherapy drugs, is associated with the problem that the target site is different from that of chemotherapy drugs [177-181]. To solve this, the chemotherapy drug PTX was loaded into the core of the $\mathrm{pH}$-sensitive triblock copolymer mPEG-PLLMA (peptide-CD)-PAsp(DBP), and sunitinib was included through $\beta$-cyclodextrin grafted to the side chain of PLLMA through the MMP-2-sensitive peptide. PTX and sunitinib (ST) co-loaded MMP-2 sensitive peptide micelles (PTX-ST-psMs) capable of site-specific drug release were prepared. 
When PTX-ST-psMs accumulate at the tumor site, the MMP-2-sensitive peptide is degraded, and ST is released. Then, it moves into cancer cells and sequentially releases PTX, thereby enhancing the antitumor effect. In vitro cell apoptosis and antiangiogenesis studies confirmed that ST can increase the therapeutic effect of PTX on cancer cells. Furthermore, in vivo studies showed that PTX-ST-psMs had superior anticancer efficacy to the control groups (PTX-loaded non-MMP-2 micelles (PTX-Ms), ST-Ms, PTX-ST-Ms), revealing that spatiotemporal controlled release can affect both TME and cancer cells, further increasing the anticancer efficacy.

\subsubsection{Spatiotemporal Drugs Release by Dual-pH-Responsive Nanocarriers}

Spatiotemporal sequential release can also be achieved by $\mathrm{pH}$ control [40]. Dong et al. designed a nanocarrier capable of dual-pH-responsive drug release, by considering the difference between the $\mathrm{pH}$ of the tumor vasculature and the $\mathrm{pH}$ inside cancer cells. First, DOX is conjugated with polyaspartate (Pasp) through a $\mathrm{pH}$-triggered hydrazone bond to form Pasp-DOX, an inactive macromolecular prodrug, so that DOX can be released in response to the $\mathrm{pH}$ conditions inside cancer cells ( $\mathrm{pH} 5-6)[182,183]$. A combination of this prodrug and combretastatin A4 (CA4), a tumor vascular inhibitor that can inhibit the growth of tumor vasculature by destroying the tumor cell skeletal structure, was formulated as a $\mathrm{pH}$-sensitive poly(ethylene glycol)-polyhistidine (PEG-Phis) polypeptide. CA4/Pasp-DOX/PEG-Phis is first protonated and then undergoes swelling in response to tumor extracellular $\mathrm{pH}$ conditions ( $\mathrm{pH} 6-7)$ in the tumor vasculature [184]. Protonation and swelling of the formulation cause the release of CA4 from the tumor vasculature to indirectly regulate the TME and promote the uptake of Pasp-DOX/PEG-Phis by tumor cells. Next, after Pasp-DOX/PEG-Phis is internalized by endosomes/lysosomes, the macromolecular prodrug PASP-DOX reacts to the intracellular $\mathrm{pH}$ (5.5) condition to release DOX, which then enter the nucleus and causes apoptosis to kill cancer cells. The site-specific drug release of CA4/Pasp-DOX/PEG-Phis was verified by testing its release profile under different $\mathrm{pH}$ conditions in PBS and by in vitro noncontact co-culture studies using human umbilical vein endothelial cells and MCF-7/ADR human breast adenocarcinoma cells resistant to DOX. Free DOX and the combination of free DOX/CA4 showed low intracellular accumulation owing to the high expression of P-gp in MCF-7/ADR, whereas CA4/Pasp-DOX/PEG-Phis showed high intracellular accumulation through endocytosis [185].

In a MCF-7/ADR tumor xenograft model, CA4/Pasp-DOX/PEG-Phis showed superior in vivo anticancer efficacy to the controls (free DOX, free CA4, free DOX and CA4 combination, Pasp-DOX, Pasp-DOX + CA4, and CA4/DOX/PEG-Phis). In addition, CA4/Pasp-DOX/PEG-Phis did not show any toxicity against leukocytes. Furthermore, the administration of CA4/Pasp-DOX/PEG-Phis to collagen, a major extracellular matrix component, significantly reduced tumor angiogenesis compared with that of controls, showing a change in the TME [31]. Thus, site-specific sequential drug release from dual-pH-responsive nanocarriers can alter the TME and exert anticancer efficacy against drug-resistant tumors by promoting the accumulation of anticancer agents in the tumor.

In summary, spatiotemporal drug release has the advantage of effectively releasing drugs to the TME and simultaneously releasing anticancer drugs to the cancer cells themselves, enabling effective anticancer treatment. However, there are also limitations in spatiotemporal release studies; only few studies have been conducted and the development has not reached the clinical trial phase.

\section{Conclusions}

Nanoparticles have the capacity to carry therapeutic drugs with various anticancer mechanisms. The anticancer effect of multidrug-loaded nanoparticles varies drastically depending on how drugs are released from nanoparticles. In this review, the pattern of drug release from nanoparticles was investigated and classified in terms of time and space. To this end, we divided drug release patterns into ratiometric drug release, which can deliver drugs to target areas by maintaining a synergistic drug ratio, and sequential release, which releases drugs over time or over space, and we discussed specific physicochemical techniques used to achieve them. Further studies on the release of various drugs 
from nanoparticles to a suitable location at a suitable time will gradually help increase the anticancer effect of multidrug-loaded nanoparticles and advance the development to the clinical trial phase.

Author Contributions: Conceptualization, M.S.Y., J.-S.K., and D.H.S.; investigation, M.S.Y., Y.J.L., and H.J.S.; writing—original draft preparation, M.S.Y., Y.J.L., H.J.S., and D.H.S.; writing-review and editing, M.S.Y., Y.J.L., H.J.S., J.-S.K., and D.H.S.; supervision, C.-W.P., S.-B.H., J.-K.J., J.-S.K., and D.H.S.; project administration, M.S.Y. and D.H.S. All authors read and agreed to the published version of the manuscript.

Funding: This research was supported by the Basic Science Research Program through the National Research Foundation of Korea (NRF) funded by the Ministry of Education (NRF-2019R1C1C1009996).

Acknowledgments: The authors would like to thank Min Jeong Jo and Ik Sup Jin for their technical assistance.

Conflicts of Interest: The authors declare no conflict of interest.

\section{References}

1. Siegel, R.L.; Miller, K.D.; Jemal, A. Cancer statistics, 2016. CA Cancer J. Clin. 2016, 66, 7-30. [CrossRef] [PubMed]

2. Shin, D.H.; Kwon, G.S. Epothilone B-based 3-in-1 polymeric micelle for anticancer drug therapy. Int. J. Pharm. 2017, 518, 307-311. [CrossRef] [PubMed]

3. Scheff, R.J.; Schneider, B.J. Non-small-cell lung cancer: Treatment of late stage disease: Chemotherapeutics and new frontiers. Semin. Interv. Radiol. 2013, 30, 191-198. [CrossRef] [PubMed]

4. Zhou, G.; Lu, Y.; Xie, J.-L.; Gao, Z.-K.; Wu, X.-B.; Yao, W.; Gu, W. Overexpression of miR-758 inhibited proliferation, migration, invasion, and promoted apoptosis of non-small cell lung cancer cells by negatively regulating HMGB. Biosci. Rep. 2019, 39, 39. [CrossRef]

5. Ascierto, P.A.; Marincola, F.M. Combination Therapy: The Next Opportunity and Challenge of Medicine; Springer: Berlin/Heidelberg, Germany, 2011.

6. Lee, J.H.; Nan, A. Combination drug delivery approaches in metastatic breast cancer. J. Drug Deliv. 2012, 2012, 1-17. [CrossRef]

7. Giaccone, G.; Pinedo, H.M. Drug resistance. Oncologist 1996, 1, 82-87. [CrossRef]

8. Ma, L.; Kohli, M.; Smith, A. Nanoparticles for Combination Drug Therapy. ACS Nano 2013, 7, $9518-9525$. [CrossRef]

9. Hu, C.-M.J.; Aryal, S.; Zhang, L. Nanoparticle-assisted combination therapies for effective cancer treatment. Ther. Deliv. 2010, 1, 323-334. [CrossRef]

10. Parhi, P.; Mohanty, C.; Sahoo, S.K. Nanotechnology-based combinational drug delivery: An emerging approach for cancer therapy. Drug Discov. Today 2012, 17, 1044-1052. [CrossRef]

11. Zhou, Q.; Zhang, L.; Yang, T.; Wu, H. Stimuli-responsive polymeric micelles for drug delivery and cancer therapy. Int. J. Nanomed. 2018, 13, 2921. [CrossRef]

12. Gupta, A.D. A review on recent advancement of cancer therapy using nanoparticles. Biochem. Mol. Biol. Lett. 2017, 3, 104.

13. Solanki, N.; Mehta, M.; Chellappan, D.K.; Gupta, G.; Hansbro, N.G.; Tambuwala, M.M.; Aa Aljabali, A.; Paudel, K.R.; Liu, G.; Satija, S.; et al. Antiproliferative effects of boswellic acid-loaded chitosan nanoparticles on human lung cancer cell line A549. Future Med. Chem. 2020, 12, 2019-2034. [CrossRef] [PubMed]

14. Qu, N.; Sun, Y.; Li, Y.; Hao, F.; Qiu, P.; Teng, L.; Xie, J.; Gao, Y. Docetaxel-loaded human serum albumin (HSA) nanoparticles: Synthesis, characterization, and evaluation. Biomed. Eng. Online 2019, 18, 11. [CrossRef] [PubMed]

15. Aljabali, A.A.A.; Bakshi, H.A.; Hakkim, F.L.; Haggag, Y.A.; Al-Batanyeh, K.M.; Al Zoubi, M.S.; Al-Trad, B.M.; Nasef, M.; Satija, S.; Mehta, M. Albumin nano-encapsulation of piceatannol enhances its anticancer potential in colon cancer via downregulation of nuclear p65 and HIF-1 $\alpha$. Cancers 2020, 12, 113. [CrossRef] [PubMed]

16. Jo, M.J.; Jo, Y.H.; Lee, Y.J.; Park, C.W.; Kim, J.S.; Hong, J.T.; Chung, Y.B.; Lee, M.K.; Shin, D.H. Physicochemical, Pharmacokinetic, and Toxicity Evaluation of Methoxy Poly(ethylene glycol)-b-Poly(d,l-Lactide) Polymeric Micelles Encapsulating Alpinumisoflavone Extracted from Unripe Cudrania tricuspidata Fruit. Pharmaceutics 2019, 11, 366. [CrossRef] [PubMed]

17. Iversen, T.-G.; Skotland, T.; Sandvig, K. Endocytosis and intracellular transport of nanoparticles: Present knowledge and need for future studies. Nano Today 2011, 6, 176-185. [CrossRef] 
18. Gmeiner, W.H.; Ghosh, S. Nanotechnology for cancer treatment. Nanotechnol. Rev. 2014, 3, 111-122. [CrossRef]

19. Wakaskar, R.R. Passive and active targeting in tumor microenvironment. Int. J. Drug Dev. Res. 2017, 9, 37-41.

20. Kolishetti, N.; Dhar, S.; Valencia, P.M.; Lin, L.Q.; Karnik, R.; Lippard, S.J.; Langer, R.; Farokhzad, O.C. Engineering of self-assembled nanoparticle platform for precisely controlled combination drug therapy. Proc. Natl. Acad. Sci. USA 2010, 107, 17939-17944. [CrossRef]

21. Hu, C.M.; Zhang, L. Nanoparticle-based combination therapy toward overcoming drug resistance in cancer. Biochem. Pharmacol. 2012, 83, 1104-1111. [CrossRef]

22. Yan, Y.; Björnmalm, M.; Caruso, F. Particle Carriers for Combating Multidrug-Resistant Cancer. ACS Nano 2013, 7, 9512-9517. [CrossRef] [PubMed]

23. Batist, G.; Gelmon, K.A.; Chi, K.N.; Miller, W.H.; Chia, S.K.; Mayer, L.D.; Swenson, C.E.; Janoff, A.S.; Louie, A.C. Safety, pharmacokinetics, and efficacy of CPX-1 liposome injection in patients with advanced solid tumors. Clin. Cancer Res. 2009, 15, 692-700. [CrossRef] [PubMed]

24. Feldman, E.J.; Lancet, J.E.; Kolitz, J.E.; Ritchie, E.K.; Roboz, G.J.; List, A.F.; Allen, S.L.; Asatiani, E.; Mayer, L.D.; Swenson, C. First-in-man study of CPX-351: A liposomal carrier containing cytarabine and daunorubicin in a fixed 5: 1 molar ratio for the treatment of relapsed and refractory acute myeloid leukemia. J. Clin. Oncol. 2011, 29, 979. [CrossRef] [PubMed]

25. Hasenstein, J.R.; Shin, H.-C.; Kasmerchak, K.; Buehler, D.; Kwon, G.S.; Kozak, K.R. Antitumor activity of Triolimus: A novel multidrug-loaded micelle containing Paclitaxel, Rapamycin, and 17-AAG. Mol. Cancer Ther. 2012, 11, 2233-2242. [CrossRef]

26. Shin, H.-C.; Alani, A.W.; Cho, H.; Bae, Y.; Kolesar, J.M.; Kwon, G.S. A 3-in-1 polymeric micelle nanocontainer for poorly water-soluble drugs. Mol. Pharm. 2011, 8, 1257-1265. [CrossRef]

27. Shin, H.-C.; Cho, H.; Lai, T.C.; Kozak, K.R.; Kolesar, J.M.; Kwon, G.S. Pharmacokinetic study of 3-in-1 poly(ethylene glycol)-block-poly(D, L-lactic acid) micelles carrying paclitaxel, 17-allylamino-17-demethoxygeldanamycin, and rapamycin. J. Control. Release 2012, 163, 93-99. [CrossRef]

28. Xu, H.L.; Fan, Z.L.; ZhuGe, D.L.; Tong, M.Q.; Shen, B.X.; Lin, M.T.; Zhu, Q.Y.; Jin, B.H.; Sohawon, Y.; Yao, Q.; et al. Ratiometric delivery of two therapeutic candidates with inherently dissimilar physicochemical property through $\mathrm{pH}$-sensitive core-shell nanoparticles targeting the heterogeneous tumor cells of glioma. Drug Deliv. 2018, 25, 1302-1318. [CrossRef]

29. Guo, Z.; Sui, J.; Ma, M.; Hu, J.; Sun, Y.; Yang, L.; Fan, Y.; Zhang, X. pH-Responsive charge switchable PEGylated $\varepsilon$-poly-l-lysine polymeric nanoparticles-assisted combination therapy for improving breast cancer treatment. J. Control. Release Off. J. Control. Release Soc. 2020, 326, 350-364. [CrossRef]

30. Miao, L.; Guo, S.; Zhang, J.; Kim, W.Y.; Huang, L. Nanoparticles with Precise Ratiometric Co-Loading and Co-Delivery of Gemcitabine Monophosphate and Cisplatin for Treatment of Bladder Cancer. Adv. Funct. Mater. 2014, 24, 6601-6611. [CrossRef]

31. Guo, S.; Lin, C.M.; Xu, Z.; Miao, L.; Wang, Y.; Huang, L. Co-delivery of cisplatin and rapamycin for enhanced anticancer therapy through synergistic effects and microenvironment modulation. ACS Nano 2014, 8, 4996-5009. [CrossRef]

32. Luo, S.; Gu, Y.; Zhang, Y.; Guo, P.; Mukerabigwi, J.F.; Liu, M.; Lei, S.; Cao, Y.; He, H.; Huang, X. Precise Ratiometric Control of Dual Drugs through a Single Macromolecule for Combination Therapy. Mol. Pharm. 2015, 12, 2318-2327. [CrossRef] [PubMed]

33. Palanikumar, L.; Jeena, M.T.; Kim, K.; Yong Oh, J.; Kim, C.; Park, M.-H.; Ryu, J.-H. Spatiotemporally and Sequentially-Controlled Drug Release from Polymer Gatekeeper-Hollow Silica Nanoparticles. Sci. Rep. 2017, 7, 46540. [CrossRef] [PubMed]

34. Zhang, L.; Zhang, M.; Zhou, L.; Han, Q.; Chen, X.; Li, S.; Li, L.; Su, Z.; Wang, C. Dual drug delivery and sequential release by amphiphilic Janus nanoparticles for liver cancer theranostics. Biomaterials 2018, 181, 113-125. [CrossRef]

35. Ye, M.; Han, Y.; Tang, J.; Piao, Y.; Liu, X.; Zhou, Z.; Gao, J.; Rao, J.; Shen, Y. A Tumor-Specific Cascade Amplification Drug Release Nanoparticle for Overcoming Multidrug Resistance in Cancers. Adv. Mater. 2017, 29, 1702342. [CrossRef] [PubMed]

36. Luan, T.; Cheng, L.; Cheng, J.; Zhang, X.; Cao, Y.; Zhang, X.; Cui, H.; Zhao, G. Tailored Design of an ROS-Responsive Drug Release Platform for Enhanced Tumor Therapy via "Sequential Induced Activation Processes". Acs Appl. Mater. Interfaces 2019, 11, 25654-25663. [CrossRef] [PubMed] 
37. Wang, K.; Yang, B.; Ye, H.; Zhang, X.; Song, H.; Wang, X.; Li, N.; Wei, L.; Wang, Y.; Zhang, H.; et al. Self-Strengthened Oxidation-Responsive Bioactivating Prodrug Nanosystem with Sequential and Synergistically Facilitated Drug Release for Treatment of Breast Cancer. ACS Appl. Mater. Interfaces 2019, 11, 18914-18922. [CrossRef] [PubMed]

38. Huang, J.; Xu, Y.; Xiao, H.; Xiao, Z.; Guo, Y.; Cheng, D.; Shuai, X. Core-Shell Distinct Nanodrug Showing On-Demand Sequential Drug Release To Act on Multiple Cell Types for Synergistic Anticancer Therapy. ACS Nano 2019, 13, 7036-7049. [CrossRef] [PubMed]

39. He, J.; Xiao, H.; Li, B.; Peng, Y.; Li, X.; Wang, Y.; Adamus, G.; Kowalczuk, M.; Shuai, X. The programmed site-specific delivery of the angiostatin sunitinib and chemotherapeutic paclitaxel for highly efficient tumor treatment. J. Mater. Chem. B 2019, 7, 4953-4962. [CrossRef]

40. Dong, Y.; Yang, J.; Liu, H.; Wang, T.; Tang, S.; Zhang, J.; Zhang, X. Site-specific drug-releasing polypeptide nanocarriers based on dual-pH response for enhanced therapeutic efficacy against drug-resistant tumors. Theranostics 2015, 5, 890. [CrossRef]

41. Zhang, R.X.; Wong, H.L.; Xue, H.Y.; Eoh, J.Y.; Wu, X.Y. Nanomedicine of synergistic drug combinations for cancer therapy-Strategies and perspectives. J. Control. Release 2016, 240, 489-503. [CrossRef]

42. Mayer, L.D.; Janoff, A.S. Optimizing combination chemotherapy by controlling drug ratios. Mol. Interv. 2007, 7, 216. [CrossRef] [PubMed]

43. Grantab, R.; Sivananthan, S.; Tannock, I.F. The penetration of anticancer drugs through tumor tissue as a function of cellular adhesion and packing density of tumor cells. Cancer Res. 2006, 66, 1033-1039. [CrossRef] [PubMed]

44. Qi, N.; Tang, B.; Liu, G.; Liang, X. Poly ( $\gamma$-glutamic acid)-coated lipoplexes loaded with Doxorubicin for enhancing the antitumor activity against liver tumors. Nanoscale Res. Lett. 2017, 12,1-9. [CrossRef] [PubMed]

45. Yallapu, M.M.; Jaggi, M.; Chauhan, S.C. Curcumin nanomedicine: A road to cancer therapeutics. Curr. Pharm. Des. 2013, 19, 1994-2010. [CrossRef]

46. Kalyane, D.; Raval, N.; Maheshwari, R.; Tambe, V.; Kalia, K.; Tekade, R.K. Employment of enhanced permeability and retention effect (EPR): Nanoparticle-based precision tools for targeting of therapeutic and diagnostic agent in cancer. Mater. Sci. Eng. C 2019, 98, 1252-1276. [CrossRef]

47. Overchuk, M.; Zheng, G. Overcoming obstacles in the tumor microenvironment: Recent advancements in nanoparticle delivery for cancer theranostics. Biomaterials 2018, 156, 217-237. [CrossRef]

48. Jin, Q.; Deng, Y.; Chen, X.; Ji, J. Rational Design of Cancer Nanomedicine for Simultaneous Stealth Surface and Enhanced Cellular Uptake. ACS Nano 2019, 13, 954-977. [CrossRef]

49. Yeung, T.; Gilbert, G.E.; Shi, J.; Silvius, J.; Kapus, A.; Grinstein, S. Membrane Phosphatidylserine Regulates Surface Charge and Protein Localization. Science 2008, 319, 210. [CrossRef]

50. Du, J.Z.; Du, X.J.; Mao, C.Q.; Wang, J. Tailor-made dual pH-sensitive polymer-doxorubicin nanoparticles for efficient anticancer drug delivery. J. Am. Chem. Soc. 2011, 133, 17560-17563. [CrossRef]

51. Cui, J.; Yan, Y.; Wang, Y.; Caruso, F. Templated Assembly of pH-Labile Polymer-Drug Particles for Intracellular Drug Delivery. Adv. Funct. Mater. 2012, 22, 4718-4723. [CrossRef]

52. Gu, Y.; Zhong, Y.; Meng, F.; Cheng, R.; Deng, C.; Zhong, Z. Acetal-linked paclitaxel prodrug micellar nanoparticles as a versatile and potent platform for cancer therapy. Biomacromolecules 2013, 14, 2772-2780. [CrossRef] [PubMed]

53. Zhu, S.; Hong, M.; Tang, G.; Qian, L.; Lin, J.; Jiang, Y.; Pei, Y. Partly PEGylated polyamidoamine dendrimer for tumor-selective targeting of doxorubicin: The effects of PEGylation degree and drug conjugation style. Biomaterials 2010, 31, 1360-1371. [CrossRef] [PubMed]

54. Ma, B.; Zhuang, W.; Wang, Y.; Luo, R.; Wang, Y. pH-sensitive doxorubicin-conjugated prodrug micelles with charge-conversion for cancer therapy. Acta Biomater. 2018, 70, 186-196. [CrossRef] [PubMed]

55. Bae, Y.; Kataoka, K. Intelligent polymeric micelles from functional poly(ethylene glycol)-poly(amino acid) block copolymers. Adv. Drug Deliv. Rev. 2009, 61, 768-784. [CrossRef] [PubMed]

56. Zou, J.; Zhang, F.; Zhang, S.; Pollack, S.F.; Elsabahy, M.; Fan, J.; Wooley, K.L. Poly(ethylene oxide)-block-polyphosphoester-graft-paclitaxel conjugates with acid-labile linkages as a $\mathrm{pH}$-sensitive and functional nanoscopic platform for paclitaxel delivery. Adv. Health Mater. 2014, 3, 441-448. [CrossRef] [PubMed] 
57. Kinoh, H.; Miura, Y.; Chida, T.; Liu, X.; Mizuno, K.; Fukushima, S.; Morodomi, Y.; Nishiyama, N.; Cabral, H.; Kataoka, K. Nanomedicines Eradicating Cancer Stem-like Cells in Vivo by pH-Triggered Intracellular Cooperative Action of Loaded Drugs. ACS Nano 2016, 10, 5643-5655. [CrossRef]

58. Zhang, M.; Chen, X.; Li, C.; Shen, X. Charge-reversal nanocarriers: An emerging paradigm for smart cancer nanomedicine. J. Control. Release Off. J. Control. Release Soc. 2020, 319, 46-62. [CrossRef]

59. Van Driessche, A.; Kocere, A.; Everaert, H.; Nuhn, L.; Van Herck, S.; Griffiths, G.; Fenaroli, F.; De Geest, B.G. pH-Sensitive Hydrazone-Linked Doxorubicin Nanogels via Polymeric-Activated Ester Scaffolds: Synthesis, Assembly, and In Vitro and In Vivo Evaluation in Tumor-Bearing Zebrafish. Chem. Mater. 2018, 30, 8587-8596. [CrossRef]

60. Lee, C.C.; Gillies, E.R.; Fox, M.E.; Guillaudeu, S.J.; Fréchet, J.M.; Dy, E.E.; Szoka, F.C. A single dose of doxorubicin-functionalized bow-tie dendrimer cures mice bearing C-26 colon carcinomas. Proc. Natl. Acad. Sci. USA 2006, 103, 16649-16654. [CrossRef]

61. Buss, J.H.; Begnini, K.R.; Bruinsmann, F.A.; Ceolin, T.; Sonego, M.S.; Pohlmann, A.R.; Guterres, S.S.; Collares, T.; Seixas, F.K. Lapatinib-Loaded Nanocapsules Enhances Antitumoral Effect in Human Bladder Cancer Cell. Front. Oncol. 2019, 9, 203. [CrossRef]

62. Lee, S.Y.; Cho, H.J. Mitochondria Targeting and Destabilizing Hyaluronic Acid Derivative-Based Nanoparticles for the Delivery of Lapatinib to Triple-Negative Breast Cancer. Biomacromolecules 2019, 20, 835-845. [CrossRef] [PubMed]

63. Gulzar, A.; Xu, J.; Wang, C.; He, F.; Yang, D.; Gai, S.; Yang, P.; Lin, J.; Jin, D.; Xing, B. Tumour microenvironment responsive nanoconstructs for cancer theranostic. Nano Today 2019, 26, 16-56. [CrossRef]

64. Gatenby, R.A.; Gillies, R.J. A microenvironmental model of carcinogenesis. Nat. Rev. Cancer 2008, 8, 56-61. [CrossRef] [PubMed]

65. Lee, E.S.; Gao, Z.; Bae, Y.H. Recent progress in tumor pH targeting nanotechnology. J. Control. Release Off. J. Control. Release Soc. 2008, 132, 164-170. [CrossRef] [PubMed]

66. Guo, S.; Wang, Y.; Miao, L.; Xu, Z.; Lin, C.M.; Zhang, Y.; Huang, L. Lipid-coated Cisplatin nanoparticles induce neighboring effect and exhibit enhanced anticancer efficacy. ACS Nano 2013, 7, 9896-9904. [CrossRef]

67. Guo, S.; Miao, L.; Wang, Y.; Huang, L. Unmodified drug used as a material to construct nanoparticles: Delivery of cisplatin for enhanced anti-cancer therapy. J. Control. Release Off. J. Control. Release Soc. 2014, 174, 137-142. [CrossRef]

68. Shin, D.H.; Kwon, G.S. Pre-clinical evaluation of a themosensitive gel containing epothilone B and mTOR/Hsp90 targeted agents in an ovarian tumor model. J. Control Release 2017, 268, 176-183. [CrossRef]

69. Schnell, C.R.; Stauffer, F.; Allegrini, P.R.; O'Reilly, T.; McSheehy, P.M.; Dartois, C.; Stumm, M.; Cozens, R.; Littlewood-Evans, A.; García-Echeverría, C.; et al. Effects of the dual phosphatidylinositol 3-kinase/mammalian target of rapamycin inhibitor NVP-BEZ235 on the tumor vasculature: Implications for clinical imaging. Cancer Res. 2008, 68, 6598-6607. [CrossRef]

70. Guba, M.; von Breitenbuch, P.; Steinbauer, M.; Koehl, G.; Flegel, S.; Hornung, M.; Bruns, C.J.; Zuelke, C.; Farkas, S.; Anthuber, M.; et al. Rapamycin inhibits primary and metastatic tumor growth by antiangiogenesis: Involvement of vascular endothelial growth factor. Nat. Med. 2002, 8, 128-135. [CrossRef]

71. Zhang, Y.; Kim, W.Y.; Huang, L. Systemic delivery of gemcitabine triphosphate via LCP nanoparticles for NSCLC and pancreatic cancer therapy. Biomaterials 2013, 34, 3447-3458. [CrossRef]

72. Li, J.; Yang, Y.; Huang, L. Calcium phosphate nanoparticles with an asymmetric lipid bilayer coating for siRNA delivery to the tumor. J. Control. Release Off. J. Control. Release Soc. 2012, 158, 108-114. [CrossRef] [PubMed]

73. Duncan, R. Polymer conjugates as anticancer nanomedicines. Nat. Rev. Cancer 2006, 6, 688-701. [CrossRef] [PubMed]

74. Bae, Y.; Diezi, T.A.; Zhao, A.; Kwon, G.S. Mixed polymeric micelles for combination cancer chemotherapy through the concurrent delivery of multiple chemotherapeutic agents. J. Control. Release 2007, 122, 324-330. [CrossRef] [PubMed]

75. Greco, F.; Vicent, M.J. Combination therapy: Opportunities and challenges for polymer-drug conjugates as anticancer nanomedicines. Adv. Drug Deliv. Rev. 2009, 61, 1203-1213. [CrossRef]

76. Sirova, M.; Strohalm, J.; Subr, V.; Plocova, D.; Rossmann, P.; Mrkvan, T.; Ulbrich, K.; Rihova, B. Treatment with HPMA copolymer-based doxorubicin conjugate containing human immunoglobulin induces long-lasting systemic anti-tumour immunity in mice. Cancer Immunol. Immunother. 2007, 56, 35-47. [CrossRef] 
77. Maeda, H.; Wu, J.; Sawa, T.; Matsumura, Y.; Hori, K. Tumor vascular permeability and the EPR effect in macromolecular therapeutics: A review. J. Control. Release 2000, 65, 271-284. [CrossRef]

78. Aryal, S.; Hu, C.M.J.; Zhang, L. Combinatorial Drug Conjugation Enables Nanoparticle Dual-Drug Delivery. Small 2010, 6, 1442-1448. [CrossRef]

79. Aryal, S.; Hu, C.-M.J.; Zhang, L. Polymeric nanoparticles with precise ratiometric control over drug loading for combination therapy. Mol. Pharm. 2011, 8, 1401-1407. [CrossRef]

80. Sengupta, S.; Eavarone, D.; Capila, I.; Zhao, G.; Watson, N.; Kiziltepe, T.; Sasisekharan, R. Temporal targeting of tumour cells and neovasculature with a nanoscale delivery system. Nature 2005, 436, 568-572. [CrossRef]

81. Liao, L.; Liu, J.; Dreaden, E.C.; Morton, S.W.; Shopsowitz, K.E.; Hammond, P.T.; Johnson, J.A. A Convergent Synthetic Platform for Single-Nanoparticle Combination Cancer Therapy: Ratiometric Loading and Controlled Release of Cisplatin, Doxorubicin, and Camptothecin. J. Am. Chem. Soc. 2014, 136, 5896-5899. [CrossRef]

82. Cheung, R.Y.; Rauth, A.M.; Ronaldson, P.T.; Bendayan, R.; Wu, X.Y. In vitro toxicity to breast cancer cells of microsphere-delivered mitomycin $C$ and its combination with doxorubicin. Eur. J. Pharm. Biopharm. 2006, 62, 321-331. [CrossRef] [PubMed]

83. De Marre, A.; Soyez, H.; Schacht, E.; Shoaibi, M.A.; Seymour, L.W.; Rihova, B. Synthesis and evaluation of macromolecular prodrugs of mitomycin C. J. Control. Release 1995, 36, 87-97. [CrossRef]

84. Cao, Y.; Chen, D.; Zhao, P.; Liu, L.; Huang, X.; Qi, C.; Liu, Y.; He, H.; Wang, Q.; Liu, Y.; et al. Intracellular Delivery of Mitomycin C with Targeted Polysaccharide Conjugates Against Multidrug Resistance. Ann. Biomed. Eng. 2011, 39, 2456-2465. [CrossRef] [PubMed]

85. Cao, Y.; Gu, Y.; Ma, H.; Bai, J.; Liu, L.; Zhao, P.; He, H. Self-assembled nanoparticle drug delivery systems from galactosylated polysaccharide-doxorubicin conjugate loaded doxorubicin. Int. J. Biol. Macromol. 2010, 46, 245-249. [CrossRef]

86. Meng, F.; Cheng, R.; Deng, C.; Zhong, Z. Intracellular drug release nanosystems. Mater. Today 2012, 15, 436-442. [CrossRef]

87. Xu, W.; Thapa, R.; Liu, D.; Nissinen, T.; Granroth, S.; Närvänen, A.; Suvanto, M.; Santos, H.A.; Lehto, V.-P. Smart Porous Silicon Nanoparticles with Polymeric Coatings for Sequential Combination Therapy. Mol. Pharm. 2015, 12, 4038-4047. [CrossRef]

88. Nam, J.; La, W.-G.; Hwang, S.; Ha, Y.S.; Park, N.; Won, N.; Jung, S.; Bhang, S.H.; Ma, Y.-J.; Cho, Y.-M.; et al. pH-Responsive Assembly of Gold Nanoparticles and "Spatiotemporally Concerted" Drug Release for Synergistic Cancer Therapy. ACS Nano 2013, 7, 3388-3402. [CrossRef]

89. Wu, M.; Lin, X.; Tan, X.; Li, J.; Wei, Z.; Zhang, D.; Zheng, Y.; Zheng, A.-X.; Zhao, B.; Zeng, Y.; et al. Photoresponsive Nanovehicle for Two Independent Wavelength Light-Triggered Sequential Release of P-gp shRNA and Doxorubicin To Optimize and Enhance Synergistic Therapy of Multidrug-Resistant Cancer. ACS Appl. Mater. Interfaces 2018, 10, 19416-19427. [CrossRef]

90. Chen, Y.; Gao, Y.; Chen, H.; Zeng, D.; Li, Y.; Zheng, Y.; Li, F.; Ji, X.; Wang, X.; Chen, F.; et al. Engineering Inorganic Nanoemulsions/Nanoliposomes by Fluoride-Silica Chemistry for Efficient Delivery/Co-Delivery of Hydrophobic Agents. Adv. Funct. Mater. 2012, 22, 1586-1597. [CrossRef]

91. Ferris, D.P.; Lu, J.; Gothard, C.; Yanes, R.; Thomas, C.R.; Olsen, J.C.; Stoddart, J.F.; Tamanoi, F.; Zink, J.I. Synthesis of biomolecule-modified mesoporous silica nanoparticles for targeted hydrophobic drug delivery to cancer cells. Small 2011, 7, 1816-1826. [CrossRef]

92. Meng, H.; Wang, M.; Liu, H.; Liu, X.; Situ, A.; Wu, B.; Ji, Z.; Chang, C.H.; Nel, A.E. Use of a lipid-coated mesoporous silica nanoparticle platform for synergistic gemcitabine and paclitaxel delivery to human pancreatic cancer in mice. ACS Nano 2015, 9, 3540-3557. [CrossRef] [PubMed]

93. Chen, F.; Hong, H.; Shi, S.; Goel, S.; Valdovinos, H.F.; Hernandez, R.; Theuer, C.P.; Barnhart, T.E.; Cai, W. Engineering of Hollow Mesoporous Silica Nanoparticles for Remarkably Enhanced Tumor Active Targeting Efficacy. Sci. Rep. 2014, 4, 5080. [CrossRef] [PubMed]

94. Singh, A.; Talekar, M.; Tran, T.-H.; Samanta, A.; Sundaram, R.; Amiji, M. Combinatorial approach in the design of multifunctional polymeric nano-delivery systems for cancer therapy. J. Mater. Chem. B 2014, 2, 8069-8084. [CrossRef] [PubMed]

95. Palanikumar, L.; Kim, H.Y.; Oh, J.Y.; Thomas, A.P.; Choi, E.S.; Jeena, M.T.; Joo, S.H.; Ryu, J.-H. Noncovalent Surface Locking of Mesoporous Silica Nanoparticles for Exceptionally High Hydrophobic Drug Loading and Enhanced Colloidal Stability. Biomacromolecules 2015, 16, 2701-2714. [CrossRef] [PubMed] 
96. Hu, X.; Liu, G.; Li, Y.; Wang, X.; Liu, S. Cell-penetrating hyperbranched polyprodrug amphiphiles for synergistic reductive milieu-triggered drug release and enhanced magnetic resonance signals. J. Am. Chem. Soc. 2015, 137, 362-368. [CrossRef]

97. Lacroix, P.M.; Graham, S.J.; Lovering, E.G. High-performance liquid chromatographic method for the assay of verapamil hydrochloride and related compounds in raw material. J. Pharm. Biomed. Anal. 1991, 9, 817-822. [CrossRef]

98. Li, X.; Zhou, L.; Wei, Y.; El-Toni, A.M.; Zhang, F.; Zhao, D. Anisotropic growth-induced synthesis of dual-compartment Janus mesoporous silica nanoparticles for bimodal triggered drugs delivery. J. Am. Chem. Soc. 2014, 136, 15086-15092. [CrossRef]

99. Zhang, L.; Chen, Y.; Li, Z.; Li, L.; Saint-Cricq, P.; Li, C.; Lin, J.; Wang, C.; Su, Z.; Zink, J.I. Tailored Synthesis of octopus-type janus nanoparticles for synergistic actively-targeted and chemo-photothermal therapy. Angew. Chem. Int. Ed. 2016, 55, 2118-2121. [CrossRef]

100. Wang, Z.; Shao, D.; Chang, Z.; Lu, M.; Wang, Y.; Yue, J.; Yang, D.; Li, M.; Xu, Q.; Dong, W.-f. Janus gold nanoplatform for synergetic chemoradiotherapy and computed tomography imaging of hepatocellular carcinoma. ACS Nano 2017, 11, 12732-12741. [CrossRef]

101. Liz-Marzán, L.M.; Grzelczak, M. Growing anisotropic crystals at the nanoscale. Science 2017, 356, $1120-1121$. [CrossRef]

102. Song, G.; Chen, M.; Zhang, Y.; Cui, L.; Qu, H.; Zheng, X.; Wintermark, M.; Liu, Z.; Rao, J. Janus iron oxides@ semiconducting polymer nanoparticle tracer for cell tracking by magnetic particle imaging. Nano Lett. 2018, 18, 182-189. [CrossRef] [PubMed]

103. Zhang, Z.; Mei, L.; Feng, S.-S. Paclitaxel drug delivery systems. Expert Opin. Drug Deliv. 2013, 10, 325-340. [CrossRef] [PubMed]

104. Sriraman, S.K.; Pan, J.; Sarisozen, C.; Luther, E.; Torchilin, V. Enhanced cytotoxicity of folic acid-targeted liposomes co-loaded with C6 ceramide and doxorubicin: In vitro evaluation on HeLa, A2780-ADR, and H69-AR cells. Mol. Pharm. 2016, 13, 428-437. [CrossRef] [PubMed]

105. Kim, H.-S.; Lee, Y.-S.; Kim, D.-K. Doxorubicin exerts cytotoxic effects through cell cycle arrest and Fas-mediated cell death. Pharmacology 2009, 84, 300-309. [CrossRef] [PubMed]

106. Sun, H.; Guo, B.; Cheng, R.; Meng, F.; Liu, H.; Zhong, Z. Biodegradable micelles with sheddable poly (ethylene glycol) shells for triggered intracellular release of doxorubicin. Biomaterials 2009, 30, 6358-6366. [CrossRef] [PubMed]

107. Chang, Y.; Cheng, Y.; Feng, Y.; Jian, H.; Wang, L.; Ma, X.; Li, X.; Zhang, H. Resonance energy transfer-promoted photothermal and photodynamic performance of gold-copper sulfide yolk-shell nanoparticles for chemophototherapy of cancer. Nano Lett. 2018, 18, 886-897. [CrossRef]

108. Wang, C.; Xu, C.; Xu, L.; Sun, C.; Yang, D.; Xu, J.; He, F.; Gai, S.; Yang, P. A novel core-shell structured upconversion nanorod as a multimodal bioimaging and photothermal ablation agent for cancer theranostics. J. Mater. Chem. B 2018, 6, 2597-2607. [CrossRef]

109. Yang, Y.; Zhu, W.; Dong, Z.; Chao, Y.; Xu, L.; Chen, M.; Liu, Z. 1D coordination polymer nanofibers for low-temperature photothermal therapy. Adv. Mater. 2017, 29, 1703588. [CrossRef]

110. Nita, M.; Grzybowski, A. The Role of the Reactive Oxygen Species and Oxidative Stress in the Pathomechanism of the Age-Related Ocular Diseases and Other Pathologies of the Anterior and Posterior Eye Segments in Adults. Oxidative Med. Cell. Longev. 2016, 2016, 3164734. [CrossRef]

111. Liu, J.; Huang, Y.; Kumar, A.; Tan, A.; Jin, S.; Mozhi, A.; Liang, X.J. pH-sensitive nano-systems for drug delivery in cancer therapy. Biotechnol. Adv. 2014, 32, 693-710. [CrossRef]

112. Ye, M.; Wang, X.; Tang, J.; Guo, Z.; Shen, Y.; Tian, H.; Zhu, W.H. Dual-channel NIR activatable theranostic prodrug for in vivo spatiotemporal tracking thiol-triggered chemotherapy. Chem. Sci. 2016, 7, 4958-4965. [CrossRef] [PubMed]

113. Liu, X.; Xiang, J.; Zhu, D.; Jiang, L.; Zhou, Z.; Tang, J.; Liu, X.; Huang, Y.; Shen, Y. Fusogenic Reactive Oxygen Species Triggered Charge-Reversal Vector for Effective Gene Delivery. Adv. Mater. 2016, 28, 1743-1752. [CrossRef] [PubMed]

114. Kroemer, G.; Jäättelä, M. Lysosomes and autophagy in cell death control. Nat. Rev. Cancer 2005, 5, 886-897. [CrossRef] [PubMed]

115. Wong, D.Y.; Hsiao, Y.L.; Poon, C.K.; Kwan, P.C.; Chao, S.Y.; Chou, S.T.; Yang, C.S. Glutathione concentration in oral cancer tissues. Cancer Lett. 1994, 81, 111-116. [CrossRef] 
116. Khynriam, D.; Prasad, S.B. Changes in endogenous tissue glutathione level in relation to murine ascites tumor growth and the anticancer activity of cisplatin. Braz. J. Med Biol. Res. 2003, 36, 53-63. [CrossRef]

117. Antunes, F.; Cadenas, E. Cellular titration of apoptosis with steady state concentrations of $\mathrm{H}(2) \mathrm{O}(2)$ : Submicromolar levels of $\mathrm{H}(2) \mathrm{O}(2)$ induce apoptosis through Fenton chemistry independent of the cellular thiol state. Free Radic. Biol. Med. 2001, 30, 1008-1018. [CrossRef]

118. Szatrowski, T.P.; Nathan, C.F. Production of large amounts of hydrogen peroxide by human tumor cells. Cancer Res. 1991, 51, 794-798.

119. De Sá Junior, P.L.; Câmara, D.A.D.; Porcacchia, A.S.; Fonseca, P.M.M.; Jorge, S.D.; Araldi, R.P.; Ferreira, A.K. The Roles of ROS in Cancer Heterogeneity and Therapy. Oxidative Med. Cell. Longev. 2017, 2017, 2467940. [CrossRef]

120. Yin, W.; Ke, W.; Chen, W.; Xi, L.; Zhou, Q.; Mukerabigwi, J.F.; Ge, Z. Integrated block copolymer prodrug nanoparticles for combination of tumor oxidative stress amplification and ROS-responsive drug release. Biomaterials 2019, 195, 63-74. [CrossRef]

121. Fang, J.; Deng, D.; Nakamura, H.; Akuta, T.; Qin, H.; Iyer, A.K.; Greish, K.; Maeda, H. Oxystress inducing antitumor therapeutics via tumor-targeted delivery of PEG-conjugated D-amino acid oxidase. Int. J. Cancer 2008, 122, 1135-1144. [CrossRef]

122. Podmore, I.D.; Griffiths, H.R.; Herbert, K.E.; Mistry, N.; Mistry, P.; Lunec, J. Vitamin C exhibits pro-oxidant properties. Nature 1998, 392, 559. [CrossRef] [PubMed]

123. Noh, J.; Kwon, B.; Han, E.; Park, M.; Yang, W.; Cho, W.; Yoo, W.; Khang, G.; Lee, D. Amplification of oxidative stress by a dual stimuli-responsive hybrid drug enhances cancer cell death. Nat. Commun. 2015, 6, 6907. [CrossRef] [PubMed]

124. Huang, G.; Chen, H.; Dong, Y.; Luo, X.; Yu, H.; Moore, Z.; Bey, E.A.; Boothman, D.A.; Gao, J. Superparamagnetic iron oxide nanoparticles: Amplifying ROS stress to improve anticancer drug efficacy. Theranostics 2013, 3, 116-126. [CrossRef] [PubMed]

125. Wu, Y.; Wang, X.; Chang, S.; Lu, W.; Liu, M.; Pang, X. $\beta$-Lapachone Induces NAD(P)H:Quinone Oxidoreductase-1- and Oxidative Stress-Dependent Heat Shock Protein 90 Cleavage and Inhibits Tumor Growth and Angiogenesis. J. Pharmacol. Exp. Ther. 2016, 357, 466-475. [CrossRef]

126. Dai, L.; Li, X.; Duan, X.; Li, M.; Niu, P.; Xu, H.; Cai, K.; Yang, H. A pH/ROS Cascade-Responsive Charge-Reversal Nanosystem with Self-Amplified Drug Release for Synergistic Oxidation-Chemotherapy. Adv. Sci. 2019, 6, 1801807. [CrossRef]

127. Juliano, R.L.; Ling, V. A surface glycoprotein modulating drug permeability in Chinese hamster ovary cell mutants. Biochim. Biophys. Acta 1976, 455, 152-162. [CrossRef]

128. Choi, B.T.; Cheong, J.; Choi, Y.H. beta-Lapachone-induced apoptosis is associated with activation of caspase-3 and inactivation of NF-kappaB in human colon cancer HCT-116 cells. Anti-Cancer Drugs 2003, 14, 845-850. [CrossRef]

129. Woo, H.J.; Park, K.Y.; Rhu, C.H.; Lee, W.H.; Choi, B.T.; Kim, G.Y.; Park, Y.M.; Choi, Y.H. Beta-lapachone, a quinone isolated from Tabebuia avellanedae, induces apoptosis in HepG2 hepatoma cell line through induction of Bax and activation of caspase. J. Med. Food 2006, 9, 161-168. [CrossRef]

130. Planchon, S.M.; Wuerzberger, S.; Frydman, B.; Witiak, D.T.; Hutson, P.; Church, D.R.; Wilding, G.; Boothman, D.A. Beta-lapachone-mediated apoptosis in human promyelocytic leukemia (HL-60) and human prostate cancer cells: A p53-independent response. Cancer Res. 1995, 55, 3706-3711.

131. Shiah, S.G.; Chuang, S.E.; Chau, Y.P.; Shen, S.C.; Kuo, M.L. Activation of c-Jun NH2-terminal kinase and subsequent CPP32/Yama during topoisomerase inhibitor beta-lapachone-induced apoptosis through an oxidation-dependent pathway. Cancer Res. 1999, 59, 391-398.

132. Zhang, L.; Chen, Z.; Yang, K.; Liu, C.; Gao, J.; Qian, F. $\beta$-Lapachone and Paclitaxel Combination Micelles with Improved Drug Encapsulation and Therapeutic Synergy as Novel Nanotherapeutics for NQO1-Targeted Cancer Therapy. Mol. Pharm. 2015, 12, 3999-4010. [CrossRef] [PubMed]

133. Wang, F.; Wang, Y.C.; Dou, S.; Xiong, M.H.; Sun, T.M.; Wang, J. Doxorubicin-tethered responsive gold nanoparticles facilitate intracellular drug delivery for overcoming multidrug resistance in cancer cells. ACS Nano 2011, 5, 3679-3692. [CrossRef] [PubMed]

134. Vallyathan, V.; Castranova, V.; Shi, X. Oxygen/Nitrogen Radicals: Cell Injury and Disease: Cell Injury and Disease; Springer Science \& Business Media: Berlin/Heidelberg, Germany, 2002; Volume 37. 
135. Leja, K.; Lewandowicz, G. Polymer Biodegradation and Biodegradable Polymers-A Review. Pol. J. Environ. Stud. 2010, 19, 255-266.

136. Vroman, I.; Tighzert, L. Biodegradable polymers. Materials 2009, 2, 307-344. [CrossRef]

137. Liu, Z.; Jiao, Y.; Wang, Y.; Zhou, C.; Zhang, Z. Polysaccharides-based nanoparticles as drug delivery systems. Adv. Drug Deliv. Rev. 2008, 60, 1650-1662. [CrossRef]

138. Cohen, J.L.; Schubert, S.; Wich, P.R.; Cui, L.; Cohen, J.A.; Mynar, J.L.; Fréchet, J.M.J. Acid-Degradable Cationic Dextran Particles for the Delivery of siRNA Therapeutics. Bioconjug. Chem. 2011, 22, 1056-1065. [CrossRef]

139. Teng, W.; Jia, F.; Han, H.; Qin, Z.; Jin, Q.; Ji, J. Polyamino acid-based gemcitabine nanocarriers for targeted intracellular drug delivery. Polym. Chem. 2017, 8, 2490-2498. [CrossRef]

140. Ding, Z.; Liu, Z.; Wei, W.; Li, Z. Preparation and characterization of plla composite scaffolds by ScCO2-induced phase separation. Polym. Compos. 2012,33, 1667-1671. [CrossRef]

141. Dånmark, S.; Finne-Wistrand, A.; Schander, K.; Hakkarainen, M.; Arvidson, K.; Mustafa, K.; Albertsson, A.C. In vitro and in vivo degradation profile of aliphatic polyesters subjected to electron beam sterilization. Acta Biomater. 2011, 7, 2035-2046. [CrossRef]

142. Sui, G.; Yang, X.; Mei, F.; Hu, X.; Chen, G.; Deng, X.; Ryu, S. Poly-L-lactic acid/hydroxyapatite hybrid membrane for bone tissue regeneration. J. Biomed. Mater. Res. Part A 2007, 82A, 445-454. [CrossRef]

143. Manavitehrani, I.; Fathi, A.; Badr, H.; Daly, S.; Negahi Shirazi, A.; Dehghani, F. Biomedical applications of biodegradable polyesters. Polymers 2016, 8, 20. [CrossRef] [PubMed]

144. Ostolska, I.; Wiśniewska, M. Application of the zeta potential measurements to explanation of colloidal Cr2O3 stability mechanism in the presence of the ionic polyamino acids. Colloid Polym. Sci. 2014, 292, 2453-2464. [CrossRef] [PubMed]

145. Ostolska, I.; Wiśniewska, M.; Nosal-Wiercińska, A.; Szabelska, A.; Gołębiowska, B. Adsorption layer structure in the system of the ionic block polyamino acid copolymers/SiO2 particles. Colloids Surf. A Physicochem. Eng. Asp. 2016, 488, 138-144. [CrossRef]

146. Singh, R.K.; Kumar, S.; Prasad, D.N.; Bhardwaj, T.R. Therapeutic journery of nitrogen mustard as alkylating anticancer agents: Historic to future perspectives. Eur. J. Med. Chem. 2018, 151, 401-433. [CrossRef] [PubMed]

147. Binko, A.M.; Traylor, Z.P.; Das, L.M.; Lu, K.Q. 1447 Vitamin D attenuates acute skin inflammation following nitrogen mustard exposure by targeting M1 macrophages. J. Investig. Dermatol. 2018, 138, S245. [CrossRef]

148. Chen, X.; Chen, H.; Lu, C.; Yang, C.; Yu, X.; Li, K.; Xie, Y. Novel mitochondria-targeted, nitrogen mustard-based DNA alkylation agents with near infrared fluorescence emission. Talanta 2016, 161, 888-893. [CrossRef]

149. Cheng, J.; Ye, F.; Dan, G.; Zhao, Y.; Zhao, J.; Zou, Z. Formation and degradation of nitrogen mustard-induced MGMT-DNA crosslinking in 16HBE cells. Toxicology 2017, 389, 67-73. [CrossRef]

150. Castaño, A.; Roy, U.; Schärer, O.D. Preparation of Stable Nitrogen Mustard DNA Interstrand Cross-Link Analogs for Biochemical and Cell Biological Studies. Methods Enzymol. 2017, 591, 415-431. [CrossRef]

151. Yan, V.C.; Butterfield, H.E.; Poral, A.H.; Yan, M.J.; Yang, K.L.; Pham, C.-D.; Muller, F.L. Why Great Mitotic Inhibitors Make Poor Cancer Drugs. Trends Cancer 2020, 6, 924-941. [CrossRef]

152. Blanco, E.; Bey, E.A.; Dong, Y.; Weinberg, B.D.; Sutton, D.M.; Boothman, D.A.; Gao, J. Beta-lapachone-containing PEG-PLA polymer micelles as novel nanotherapeutics against NQO1overexpressing tumor cells. J. Control. Release Off. J. Control. Release Soc. 2007, 122, 365-374. [CrossRef]

153. Blanco, E.; Bey, E.A.; Khemtong, C.; Yang, S.G.; Setti-Guthi, J.; Chen, H.; Kessinger, C.W.; Carnevale, K.A.; Bornmann, W.G.; Boothman, D.A.; et al. Beta-lapachone micellar nanotherapeutics for non-small cell lung cancer therapy. Cancer Res. 2010, 70, 3896-3904. [CrossRef] [PubMed]

154. Gaucher, G.; Marchessault, R.H.; Leroux, J.C. Polyester-based micelles and nanoparticles for the parenteral delivery of taxanes. J. Control. Release Off. J. Control. Release Soc. 2010, 143, 2-12. [CrossRef] [PubMed]

155. Du, J.; Lane, L.A.; Nie, S. Stimuli-responsive nanoparticles for targeting the tumor microenvironment. J. Control. Release Off. J. Control. Release Soc. 2015, 219, 205-214. [CrossRef] [PubMed]

156. Marusyk, A.; Almendro, V.; Polyak, K. Intra-tumour heterogeneity: A looking glass for cancer? Nat. Rev. Cancer 2012, 12, 323-334. [CrossRef]

157. Eder, K.; Kalman, B. The Dynamics of Interactions Among Immune and Glioblastoma Cells. Neuromol. Med. 2015, 17, 335-352. [CrossRef]

158. Waghray, M.; Yalamanchili, M.; di Magliano, M.P.; Simeone, D.M. Deciphering the role of stroma in pancreatic cancer. Curr. Opin. Gastroenterol. 2013, 29, 537-543. [CrossRef] 
159. Criscitiello, C.; Esposito, A.; Curigliano, G. Tumor-stroma crosstalk: Targeting stroma in breast cancer. Curr. Opin. Oncol. 2014, 26, 551-555. [CrossRef]

160. Lee, J.H.; Kang, S.; Ahn, M.; Jang, H.; Min, D.H. Development of Dual-Pore Coexisting Branched Silica Nanoparticles for Efficient Gene-Chemo Cancer Therapy. Small 2018, 14, 1702564. [CrossRef]

161. Greenhough, A.; Smartt, H.J.; Moore, A.E.; Roberts, H.R.; Williams, A.C.; Paraskeva, C.; Kaidi, A. The COX-2/PGE2 pathway: Key roles in the hallmarks of cancer and adaptation to the tumour microenvironment. Carcinogenesis 2009, 30, 377-386. [CrossRef]

162. Ferrara, N. Pathways mediating VEGF-independent tumor angiogenesis. Cytokine Growth Factor Rev. 2010, 21, 21-26. [CrossRef]

163. Kelly, M.G.; Alvero, A.B.; Chen, R.; Silasi, D.A.; Abrahams, V.M.; Chan, S.; Visintin, I.; Rutherford, T.; Mor, G. TLR-4 signaling promotes tumor growth and paclitaxel chemoresistance in ovarian cancer. Cancer Res. 2006, 66, 3859-3868. [CrossRef] [PubMed]

164. Chen, R.; Alvero, A.B.; Silasi, D.A.; Mor, G. Inflammation, cancer and chemoresistance: Taking advantage of the toll-like receptor signaling pathway. Am. J. Reprod. Immunol. 2007, 57, 93-107. [CrossRef] [PubMed]

165. Kalgutkar, A.S.; Zhao, Z. Discovery and design of selective cyclooxygenase-2 inhibitors as non-ulcerogenic, anti-inflammatory drugs with potential utility as anti-cancer agents. Curr. Drug Targets 2001, 2, 79-106. [CrossRef] [PubMed]

166. Sheng, H.; Shao, J.; Morrow, J.D.; Beauchamp, R.D.; DuBois, R.N. Modulation of apoptosis and Bcl-2 expression by prostaglandin E2 in human colon cancer cells. Cancer Res. 1998, 58, 362-366. [PubMed]

167. Coussens, L.M.; Zitvogel, L.; Palucka, A.K. Neutralizing tumor-promoting chronic inflammation: A magic bullet? Science 2013, 339, 286-291. [CrossRef] [PubMed]

168. Edelman, M.J.; Wang, X.; Hodgson, L.; Cheney, R.T.; Baggstrom, M.Q.; Thomas, S.P.; Gajra, A.; Bertino, E.; Reckamp, K.L.; Molina, J.; et al. Phase III Randomized, Placebo-Controlled, Double-Blind Trial of Celecoxib in Addition to Standard Chemotherapy for Advanced Non-Small-Cell Lung Cancer With Cyclooxygenase-2 Overexpression: CALGB 30801 (Alliance). J. Clin. Oncol. Off. J. Am. Soc. Clin. Oncol. 2017, 35, 2184-2192. [CrossRef] [PubMed]

169. Park, J.H.; McMillan, D.C.; Horgan, P.G.; Roxburgh, C.S. The impact of anti-inflammatory agents on the outcome of patients with colorectal cancer. Cancer Treat. Rev. 2014, 40, 68-77. [CrossRef] [PubMed]

170. Takhar, H.; Singhal, N.; Mislang, A.; Kumar, R.; Kim, L.; Selva-Nayagam, S.; Pittman, K.; Karapetis, C.; Borg, M.; Olver, I.N.; et al. Phase II study of celecoxib with docetaxel chemoradiotherapy followed by consolidation chemotherapy docetaxel plus cisplatin with maintenance celecoxib in inoperable stage III nonsmall cell lung cancer. Asia-Pac. J. Clin. Oncol. 2018, 14, 91-100. [CrossRef]

171. Mohammed, A.; Yarla, N.S.; Madka, V.; Rao, C.V. Clinically Relevant Anti-Inflammatory Agents for Chemoprevention of Colorectal Cancer: New Perspectives. Int. J. Mol. Sci. 2018, 19, 2332. [CrossRef]

172. Süleyman, H.; Demircan, B.; Karagöz, Y. Anti-inflammatory and side effects of cyclooxygenase inhibitors. Pharmacol. Rep. 2007, 59, 247-258.

173. Nagase, H.; Fields, G.B. Human matrix metalloproteinase specificity studies using collagen sequence-based synthetic peptides. Biopolymers 1996, 40, 399-416. [CrossRef]

174. Dorresteijn, R.; Billecke, N.; Schwendy, M.; Pütz, S.; Bonn, M.; Parekh, S.H.; Klapper, M.; Müllen, K. Polylactide-block-Polypeptide-block-Polylactide Copolymer Nanoparticles with Tunable Cleavage and Controlled Drug Release. Adv. Funct. Mater. 2014, 24, 4026-4033. [CrossRef]

175. Shuai, X.; Merdan, T.; Unger, F.; Wittmar, M.; Kissel, T. Novel Biodegradable Ternary Copolymers hy-PEI-g-PCL-b-PEG: Synthesis, Characterization, and Potential as Efficient Nonviral Gene Delivery Vectors. Macromolecules 2003, 36, 5751-5759. [CrossRef]

176. Shuai, X.; Ai, H.; Nasongkla, N.; Kim, S.; Gao, J. Micellar carriers based on block copolymers of poly(epsilon-caprolactone) and poly(ethylene glycol) for doxorubicin delivery. J. Control. Release Off. J. Control. Release Soc. 2004, 98, 415-426. [CrossRef] [PubMed]

177. Roskoski, R., Jr. Sunitinib: A VEGF and PDGF receptor protein kinase and angiogenesis inhibitor. Biochem. Biophys. Res. Commun. 2007, 356, 323-328. [CrossRef]

178. Bergh, J.; Bondarenko, I.M.; Lichinitser, M.R.; Liljegren, A.; Greil, R.; Voytko, N.L.; Makhson, A.N.; Cortes, J.; Lortholary, A.; Bischoff, J.; et al. First-line treatment of advanced breast cancer with sunitinib in combination with docetaxel versus docetaxel alone: Results of a prospective, randomized phase III study. J. Clin. Oncol. Off. J. Am. Soc. Clin. Oncol. 2012, 30, 921-929. [CrossRef] 
179. Camidge, D.R.; Blais, N.; Jonker, D.J.; Soulières, D.; Doebele, R.C.; Ruiz-Garcia, A.; Thall, A.; Zhang, K.; Laurie, S.A.; Chao, R.C.; et al. Sunitinib combined with pemetrexed and cisplatin: Results of a phase I dose-escalation and pharmacokinetic study in patients with advanced solid malignancies, with an expanded cohort in non-small cell lung cancer and mesothelioma. Cancer Chemother. Pharmacol. 2013, 71, 307-319. [CrossRef]

180. Galsky, M.D.; Hahn, N.M.; Powles, T.; Hellerstedt, B.A.; Lerner, S.P.; Gardner, T.A.; Yu, M.; O’Rourke, M.; Vogelzang, N.J.; Kocs, D.; et al. Gemcitabine, Cisplatin, and sunitinib for metastatic urothelial carcinoma and as preoperative therapy for muscle-invasive bladder cancer. Clin. Genitourin. Cancer 2013, 11, 175-181. [CrossRef]

181. Christensen, J.G. A preclinical review of sunitinib, a multitargeted receptor tyrosine kinase inhibitor with anti-angiogenic and antitumour activities. Ann. Oncol. Off. J. Eur. Soc. Med. Oncol. 2007, 18 Suppl 10, x3-10. [CrossRef]

182. Bae, Y.; Fukushima, S.; Harada, A.; Kataoka, K. Design of environment-sensitive supramolecular assemblies for intracellular drug delivery: Polymeric micelles that are responsive to intracellular $\mathrm{pH}$ change. Angew. Chem. 2003, 115, 4788-4791. [CrossRef]

183. Rihova, B.; Etrych, T.; Sirova, M.; Kovar, L.; Hovorka, O.; Kovar, M.; Benda, A.; Ulbrich, K. Synergistic action of doxorubicin bound to the polymeric carrier based on N-(2-hydroxypropyl) methacrylamide copolymers through an amide or hydrazone bond. Mol. Pharm. 2010, 7, 1027-1040. [CrossRef] [PubMed]

184. Lin, W.; Kim, D. pH-Sensitive micelles with cross-linked cores formed from polyaspartamide derivatives for drug delivery. Langmuir 2011, 27, 12090-12097. [CrossRef] [PubMed]

185. Duan, X.; Xiao, J.; Yin, Q.; Zhang, Z.; Yu, H.; Mao, S.; Li, Y. Smart pH-sensitive and temporal-controlled polymeric micelles for effective combination therapy of doxorubicin and disulfiram. ACS Nano 2013, 7, 5858-5869. [CrossRef] [PubMed]

Publisher's Note: MDPI stays neutral with regard to jurisdictional claims in published maps and institutional affiliations.

(C) 2020 by the authors. Licensee MDPI, Basel, Switzerland. This article is an open access article distributed under the terms and conditions of the Creative Commons Attribution (CC BY) license (http://creativecommons.org/licenses/by/4.0/). 